\title{
Therapeutic Nanoparticles and Their Targeted Delivery Applications
}

\author{
Abuzer Alp Yetisgin ${ }^{1}\left(\mathbb{D}\right.$, Sibel Cetinel ${ }^{2} \mathbb{D}$, Merve Zuvin ${ }^{3}$, Ali Kosar ${ }^{3,4}\left(\mathbb{D}\right.$ and Ozlem Kutlu ${ }^{2,4, *}$ \\ 1 Materials Science and Nano-Engineering Program, Faculty of Engineering and Natural Sciences, \\ Sabanci University, Istanbul 34956, Turkey; yalp@sabanciuniv.edu \\ 2 Nanotechnology Research and Application Center (SUNUM), Sabanci University, Istanbul 34956, Turkey; \\ cetinel@sabanciuniv.edu \\ 3 Mechatronics Engineering Program, Faculty of Engineering and Natural Sciences, Sabanci University, \\ Istanbul 34956, Turkey; mervezuvin@sabanciuniv.edu (M.Z.); ali.kosar@sabanciuniv.edu (A.K.) \\ 4 Center of Excellence for Functional Surfaces and Interfaces for Nano Diagnostics (EFSUN), \\ Sabanci University, Istanbul 34956, Turkey \\ * Correspondence: ozlemkutlu@sabanciuniv.edu; Tel.: +90-2164839000-2413; Fax: +90-2164839885
}

Academic Editor: Zacharias Suntres

Received: 25 March 2020; Accepted: 26 April 2020; Published: 8 May 2020

\begin{abstract}
Nanotechnology offers many advantages in various fields of science. In this regard, nanoparticles are the essential building blocks of nanotechnology. Recent advances in nanotechnology have proven that nanoparticles acquire a great potential in medical applications. Formation of stable interactions with ligands, variability in size and shape, high carrier capacity, and convenience of binding of both hydrophilic and hydrophobic substances make nanoparticles favorable platforms for the target-specific and controlled delivery of micro- and macromolecules in disease therapy. Nanoparticles combined with the therapeutic agents overcome problems associated with conventional therapy; however, some issues like side effects and toxicity are still debated and should be well concerned before their utilization in biological systems. It is therefore important to understand the specific properties of therapeutic nanoparticles and their delivery strategies. Here, we provide an overview on the unique features of nanoparticles in the biological systems. We emphasize on the type of clinically used nanoparticles and their specificity for therapeutic applications, as well as on their current delivery strategies for specific diseases such as cancer, infectious, autoimmune, cardiovascular, neurodegenerative, ocular, and pulmonary diseases. Understanding of the characteristics of nanoparticles and their interactions with the biological environment will enable us to establish novel strategies for the treatment, prevention, and diagnosis in many diseases, particularly untreatable ones.
\end{abstract}

Keywords: nanotechnology; therapeutic nanoparticles; targeted delivery; diseases treatment

\section{Introduction}

Nanomedicine is an emerging approach for the implementation of nanotechnological systems in disease diagnosis and therapy. This branch of nanotechnology can be classified in two main categories: nanodevices and nanomaterials. Nanodevices are miniature devices at nanoscale including microarrays [1,2] and some intelligent machines like respirocytes [3]. Nanomaterials contain particles smaller than 100 nanometers $(\mathrm{nm})$ in at least one dimension.

Recent explorations of biomedical science resulted in the successful improvement of therapeutic agents' design in disease treatment. However, there is a major obstacle before the treatment efficiency of various diseases, which is the delivery of therapeutic agents to the target area. The application of conventional therapeutic agents has limitations such as non-selectivity, undesirable side effects, low efficiency, and poor biodistribution [4]. Therefore, the focus of current research activities is 
to design well-controlled and multifunctional delivery systems. Association of therapeutic agents with nanoparticles exhibiting unique physicochemical and biological properties and designing their pathways for suitable targeting is a promising approach in delivering a wide range of molecules to certain locations in the body [5]. This targeted strategy enhances the concentration of therapeutic agent in cells/tissues; thereby, low doses can be used, particularly if there is a contradiction between the therapeutic activity and the toxic effects of the agent. Increasing concentration of therapeutic agents in-target location also improves their therapeutic index by enhancing the efficacy and/or increasing the tolerability in biological systems. Water-insoluble therapeutic agents can also be combined with nanoparticles, which can protect them from physiological barriers and improve their bioavailability. On the other hand, association of therapeutic nanoparticles with contrast agents provides a way of tracking their pathway and imaging their delivery location in in vivo systems.

The aforementioned advantages enable the targeted therapeutic nanoparticles utilization in various fields of medicine. Here, we summarized the physicochemical properties of nanoparticles making them crucial vehicles in nanomedicine and provide a review of the last decade for therapeutic nanoparticles and their targeted delivery applications in various disorders such as cancer and neurodegenerative diseases.

\section{Designing Nanoparticles for Therapeutics}

Targeted therapy in disease treatment is the approach of delivering appropriate amounts of therapeutic agent for a prolonged period to the affected area within the body. To achieve this, development of safer and more effective therapeutic nanoparticles is crucial and one of the ultimate goals of nanomedicine.

As soon as nanoparticles enter to the bloodstream, they are prone to aggregation and protein opsonization (protein binding to nanoparticle surface as a tag for immune system recognition). The opsonized nanoparticles could be cleared from the bloodstream by phagocytosis or filtration in the liver, spleen, and kidney. This rapid and non-specific clearance by the immune system results in decreased retention time and thus limits bioavailability. By decorating the nanoparticle surface with polyethylene glycol (PEG), carbohydrates, acetyl groups, or protein moieties (arginine-glycine-aspartate (RGD) peptide, albumin), retention time can be altered [6]. However, such surface modification can also alter the recognition ability for targeted delivery. Thus, the cleanability and biodistribution of therapeutic nanoparticles should be well concerned during the design process.

Size is another important factor playing role in controlling circulation and biodistribution of therapeutic nanoparticles. Nanoparticles smaller than $10 \mathrm{~nm}$, can be easily cleared by physiological systems (filtration through the kidney), while particles larger than $200 \mathrm{~nm}$ may be cleared by phagocytic cells in the reticuloendothelial system (RES). Accordingly, therapeutic nanoparticles with a size of $<100 \mathrm{~nm}$ have longer circulation time in the bloodstream. Many studies reported that therapeutic nanoparticles in 20-200 nm size showed a higher accumulation rate in tumors because they cannot be recognized by the RES and filtrated by the kidney [7-9]. Additionally, blood vessels in tumor areas are higher in number and larger in volume compared to normal tissues. Therefore, nanoparticles with appropriate sizes can reach to the tumor area relatively easily and accumulate for a longer time, which is known as the enhanced permeability and retention (EPR) effect [10,11]. In fact, passive targeting is utilized to accumulate nanoparticles to the tumor site, which is done without functionalizing nanoparticles with targeting moiety. However, in active targeting, the surface of the nanoparticle is coupled with at least one kind of targeting moiety such as, proteins, peptides, nucleic acids, antibodies, or small molecules [12].

Most of the nanoparticles are taken up within the cells by endocytosis through either clathrin- or caveolae-dependent mechanisms [13]. The shape of nanoparticles is also critical for biodistribution due to their internalization by the targeted cells. For instance, rod-shaped cationic nanoparticles are easier targets for endosomal uptake than cationic nanoparticles of other shapes, suggesting that these nanoparticles may be comprehended by immune system cells as rod-shaped bacteria [14]. 
Surface charge of therapeutic nanoparticles plays an important role in their clearance and targeted delivery. Positively charged nanoparticles generate a higher immune response compared to neutral or negatively charged nanoparticles. Additionally, nanoparticles with a surface potential between -10 and $+10 \mathrm{mV}$ are shown to be less susceptible to phagocytosis and non-specific interactions [7,9]. However, the ideal range could depend on the nanoparticle material. Surface charge is also closely related to $\mathrm{pH}$ sensibility of nanoparticles. Such nanoparticles can be designed to recognize and locate in specific compartments of the cell. For example, acidic nanoparticles can be targeted to endosomes or lysosomes for releasing their cargo, each of which has a $\mathrm{pH}$ of $<6.0[8,15,16]$.

Surface modification of nanoparticles with long-chain polymers such as polyethylene glycol (PEG) was shown to minimize non-specific protein absorption onto the nanoparticle surface. Due to its intrinsic physicochemical properties, PEG is a favorable polymer for therapeutic nanoparticles, which decreases their phagocytic uptake and reduces their accumulation in non-target organs [17]. Factors such as length, shape, and density of PEG chains affecting surface hydrophilicity and phagocytosis, should be considered before PEGylation of therapeutic nanoparticles. Conjugation of targeting ligands to the surface of PEGylated nanoparticles can improve the target-specific delivery of nanoparticles; however, it also affects their biodistribution.

\section{Types of Therapeutic Nanoparticles}

Nanomaterials can be classified in two main categories: Nano-structured and nanocrystalline. Nano-structured materials can further be categorized into polymer-based, non-polymeric, and lipid-based nanoparticles. Polymer-based nanoparticles include dendrimers, nanoparticles, micelles, nanogels, protein nanoparticles, and drug conjugates. Non-polymeric nanoparticles include carbon nanotubes, nanodiamonds, metallic nanoparticles, quantum dots, and silica-based nanoparticles. Lipid-based nanoparticles can be divided into liposomes and solid lipid nanoparticles. So far, the majority of the nanoparticles clinically approved for therapeutic use are polymer-based or lipid-based components. Apart from polymer-based, non-polymeric, or lipid-based nano-structured particles, nanocrystalline particles that are formed by the combination of therapeutic agents in crystalline form are also used in some clinical applications (Figures 1 and 2). In this section, we summarized different types of clinically used nanoparticles and their specificity for therapeutic applications, as well as their current delivery strategies in challenging pathophysiological conditions.

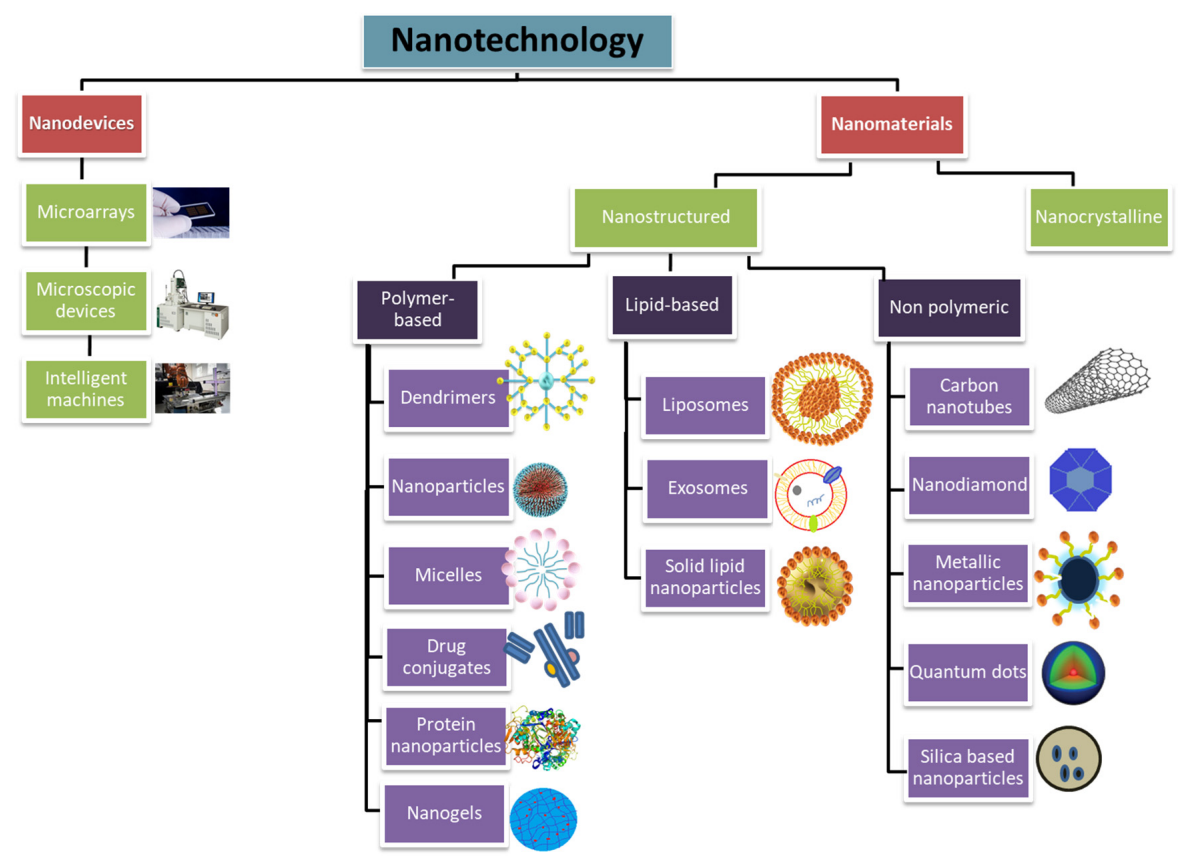

Figure 1. Elements of nanotechnology, which are utilized in therapeutic applications. 


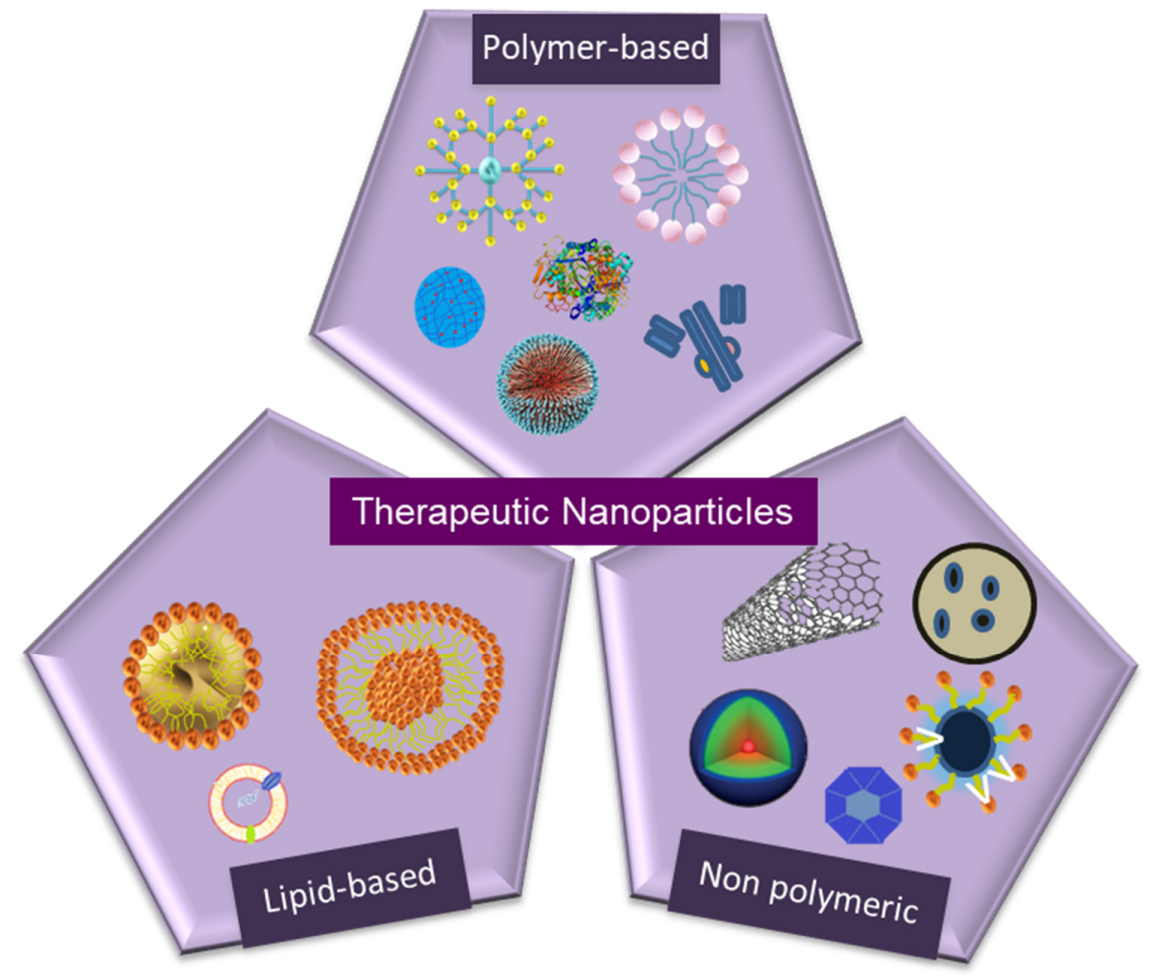

Figure 2. Schematic representations of the therapeutic nanoparticles.

\subsection{Nano-Structured Particles}

\subsubsection{Polymer-Based Particles}

\section{Dendrimers}

Dendrimers are widely used polymers in clinical applications due to their hyperbranched, compartmentalized structure, and high monodispersity. Controlling the number of branches in these polymer-based nanoparticles allows their fabrication in very small sizes (1-5 nm). They can be fabricated by polymerization in spherical shape, which leads to the formation of cavities within the dendrimer molecule. Thus, high entrapment efficiency is obtained with high-generation dendrimers, e.g. dendrimers containing more than 64 surface groups, when compared to smaller dendrimers and these are used for the delivery of therapeutic agents. Additionally, dendrimers contain free end groups, which can be easily modified/used for the conjugation of biocompatible compounds to enhance low cytotoxicity and high bio-permeability of the molecule. Such surface modifications can also be applied to improve the target-specific delivery of therapeutic agents. Assembling dendrimers by either encapsulation or complexation makes them attractive vehicles for the concomitant delivery of biologically active molecules such as vaccines, drugs, and genes to the target locations. Currently, mono- or copolymers, such as polyethyleneimine, polyamidoamine, poly(propyleneimine), chitin, etc., are used for therapeutic applications in the form of dendrimers [18,19].

\section{Nanoparticles}

Polymer-based nanoparticles, synthetic or natural, provide an alternative way for therapeutic applications due to certain characteristics, such as biocompatibility, non-immunogenicity, non-toxicity, and biodegradability [20]. In order to decrease the immunogenicity and toxicity of synthetic polymers, like polycaprolactone (PCL), polylactic acid (PLA), and their monomers, the polyester forms are used. On the other hand, natural polymer-based nanoparticles such as chitosan, gelatin, albumin, and alginate seem to overcome toxicity issues and provide significant improvement in the efficiency of therapeutic agents compared to conventional methods. Polymeric nanoparticles are considered as the 
matrix system, in which the matrix is uniformly dispersed. They can be classified as nanocapsules or nanospheres depending on their composition. In nanocapsules, a unique polymer membrane encloses therapeutic agents, whereas the therapeutic agents are directly dispersed throughout or within the polymer matrix in nanospheres [21]. Existence of a multitude of preparation methods of polymeric nanoparticles can control the release characteristics of incorporated therapeutic agents, which allows the delivery of a higher concentration of agents to the target location. Moreover, the surface of polymeric nanoparticles could be easily modified and functionalized with a specific recognition ligand which increases the specificity of therapeutic agents in targeted tissue.

\section{Micelles}

Polymeric micelles are mostly used for the systemic delivery of water-insoluble therapeutic agents. They are in $<100 \mathrm{~nm}$ size and formed in solution as aggregates. The component molecules of polymeric micelles are arranged in spheroidal structure, in which a mantle of hydrophilic groups surrounds hydrophobic cores. The existence of hydrophilic surface contributes to their protection from nonspecific uptake by the reticuloendothelial system ensuring their high stability within physiological systems. On the other hand, the hydrophobic core of polymeric micelles can physically trap the water-insoluble, hydrophobic therapeutic agents. The component molecules can also be covalently linked to this hydrophobic core. Consequently, the dynamic structure of polymeric micelles provides a prominent delivery system for therapeutic agents, which allows versatile loading capacity, conjugation of targeted ligands, and lower rate of dissolution [22].

\section{Drug Conjugates}

Conjugation of polymers with drug molecules is generally used for low molecular weight agents, particularly in cancer treatment. This conjugation increases the overall molecular weight of drugs, which induces the pharmacokinetic disposition in the cells. Polymer-drug conjugates serve as carriers with high solubility and stability and promote an EPR effect in cancer cells [23]. Covalently conjugated polymer-drugs are shown to be more reliable for sustained drug release and enhanced drug capacity [24]. There are $\mathrm{pH}$-sensitive polymeric drug conjugates, which are made by utilizing $\mathrm{pH}$-responsive chemical bonds between polymer and drug. Thus, the $\mathrm{pH}$ sensitivity of the nanoparticle is used for controlled drug release in the tumor site due to its acidic environment $[25,26]$. It is also reported that polymeric drug conjugates increase the bioavailability of the drug, for instance, shown with paclitaxel and doxorubicin combination therapy $[24,27,28]$.

\section{Protein Nanoparticles}

Viruses are very efficient and natural carrier systems for transferring their genetic material, which is encapsulated by the capsid proteins. Virus-like particles (VLP), a type of protein nanoparticles, are defined as nano-carrier systems, which have a morphologically similar, virus-isolated structure but do not include the viral genetic material [29,30]. Additionally, caged proteins (CP) are defined as self-assembled protein nanostructures, which are morphologically similar to viruses, however, not deriving from viruses. The VLPs and CPs are attractive nano-carrier systems for the development of the vaccines for cancer because they can induce antigen-specific immune responses against cancer cells [31]. Moreover, there are protein nanoparticles made by self-assembly of protein polymers, which are isolated proteins from animal or plant origin such as collagen, gelatin, silk, albumin, elastin, and soy. Through genetic engineering, protein polymers are self-assembled into functional drug delivery carriers with advantages of polymer-based nanoparticles $[32,33]$. Abraxane ${ }^{\circledR}$ is an FDA-approved protein nanoparticle drug, enabling paclitaxel delivery by albumin. On the other hand, an HIV vaccine made from VLPs led to critical developments, which accelerated research on protein nanoparticles for clinical use [34]. 
Nanogels

The gels are defined as non-fluid colloidal or polymeric networks that swell when in contact with fluid. A nanogel is considered as a particle of gel with similar properties, however, with a diameter of less than $100 \mathrm{~nm}$ by the International Union for Pure and Applied Chemistry (IUPAC) [35]. The swelling property with flexible size and high water content of the nanogels is the result of physically or chemically cross-linked natural or synthetic polymers [36,37]. The first reported nanogel was prepared by physical cross-linking of amphiphilic polysaccharides, where cholesterol-bearing pullulans are self-assembled (by hydrophobic interactions) into nanogels in water [36,38]. The nanogels have some advantages compared to other nano-carrier systems such as decreased untimely drug leakage, encapsulating various therapeutic molecules in the same formulation, and easy administration through parental or mucosal routes. The nanogels are used in various applications, including biosensors, biochemical separation, cell culture, bio-catalysis, drug delivery, antitumor therapy, and so on. Among these, delivery of therapeutics such as nucleic acids, vaccines, cytokines, and nasal vaccines are the most widely studied applications of nanogels $[36,37,39]$.

\subsubsection{Non-Polymeric Particles}

\section{Carbon Nanotubes}

Carbon nanotubes are carbon-based tubular structures $1 \mathrm{~nm}$ in diameter and 1-100 $\mathrm{nm}$ in length [40]. These structures can be obtained by wrapping a single layer of graphite called graphene into a seamless cylinder. The configuration of carbon nanotubes includes single-walled nanotubes (SWNTs), multi-walled nanotubes (MWNTs), and C60 fullerenes. The size and stable geometric shape of carbon nanotubes make them an attractive non-polymeric carrier for therapeutic agents. Particularly, SWNTs and C60 fullerenes have internal diameters of 1-2 nm, which is equivalent to about half of the average DNA helix diameter [41]. The SWNTs and MWNTs can enter the cell by endocytosis or by direct insertion through the cell membrane. Fullerenes differ in the arrangement of their graphite cylinders and the presence of a high number of conjugated double bonds in their core structure. Experiments with fullerenes have shown that they can be used for the delivery of therapeutics like antibiotics and antiviral and anti-cancer agents [42-45]. Additionally, they can protect the injured mitochondria by providing free radicals [46]. This feature allows for the tissue-selective targeting of mitochondria that can be used for delivering therapeutic agents [47].

Nanodiamonds (NDs)

Nanodiamonds (NDs) are members of carbon-based nanomaterials with a diameter of less than $100 \mathrm{~nm}$ and different shapes with two types of discrete facets, which are generated from various methods, such as the detonation, chemical vapor deposition (CVD), and high-pressure/high-temperature methods [48,49]. The oldest and most commonly used ND preparation is the detonation method, in which NDs are produced by activating a controlled explosion on carbon-containing precursors in a closed chamber. NDs that are prepared by this method usually contain $\mathrm{sp}^{2}$ carbon on the surface, and the electrostatic potential of surface is dependent on shape and structure of the NDs [50-52]. The CVD method is preferable for depositing NDs onto various substrates as thin films. The produced ND thin films are of high quality with low defects [53].

NDs have unique properties, including surface electrostatic properties, low cytotoxicity by a chemically inert core, and low photo-bleaching by the addition of nitrogen defects and can be functionalized by immobilization of various types of biomolecules, which make them remarkable for biomedical applications such as magnetic resonance imaging (MRI), synthesis of contact lenses, and drug delivery for cancer therapy. NDs can be coupled with gadolinium [Gd] (III) as a contrast agent for MRI, and the signal generated from this complex is several times higher compared to Gd (III)-based contrast agents [48-50]. 


\section{Metallic Nanoparticles}

Metallic nanoparticles used in medical applications are 1-100 nm in size and mostly made up of cobalt, nickel, iron, gold, and their respective oxides like magnetite, maghemite, cobalt ferrite, and chromium dioxide. They can be synthesized and modified with versatile functional chemical groups, which allows them to be decorated with various molecules including therapeutic agents, biological molecules like peptides, proteins, and DNA. As a carrier, they provide unique characteristics such as magnetic properties besides stability and biocompatibility. Thus, magnetic nanoparticles can be targeted to a specific location in the body by using an external magnetic field. Magnetic susceptibility, defined as the ratio of induced magnetization to the applied field, is an important parameter for their medical use. For example, super-paramagnetic iron oxide nanoparticles (SPIONs) have a large magnetic susceptibility, and thus, they are widely used in clinics as contrast agents for magnetic resonance imaging [54]. Likewise, super-paramagnetic properties facilitate the stable delivery of therapeutic agents to the body/cell and proper accumulation at the target tissue providing a reproducible and safe treatment approach $[41,55]$. When metallic nanoparticles are subjected to an alternating magnetic field, they can produce heat that is called magnetic hyperthermia, which enables their use in the ablation of tumors for cancer treatment [56,57].

Gold nanoparticles (AuNP) are widely used metallic nanoparticles, especially in cancer diagnosis and therapy. The reason for this is the unique optical and localized surface plasmon resonance (LSPR) and relatively low cytotoxicity due to the inert nature of gold. When the light with appropriate wavelength is administered to AuNPs as external stimuli, due to the LSPR property, they exhibit photothermal conversion and heat up the targeted tumor tissue to kill cancer cells. Besides, AuNPs are used for drug delivery, where (at the targeted site) the light irradiation can trigger the drug release $[58,59]$. Moreover, AuNPs' optical and LSPR properties can be tailored for applications such as imaging, optical and electrochemical detection, diagnosis, and photothermal therapy $[60,61]$.

\section{Quantum Dots}

Quantum dots (QDs) are tiny particles or nanocrystals of a semiconducting material with diameters in the range of 2-10 $\mathrm{nm}$. These particles consist of a semiconductor inorganic core such as CdSe and an aqueous organic coated shell such as $\mathrm{ZnS}$ [62]. QDs produce distinctive fluorescence colors that are partly the result of unusually high surface-to-volume ratios for such particles. The core structure of QDs determines the color emitted, while the outer aqueous shell can be used for conjugation of biomolecules such as peptides, protein, or DNA [63]. QDs can also carry a cap, which improves their solubility in aqueous buffers. Due to their narrow emission, bright fluorescence, and high photo-stability, QDs can be used for tracking therapeutic agents within the cells/tissues [64,65]. Although the medical use of QDs is still debated, their surfaces for versatile bioconjugation, adaptable photophysical properties for multiplexed detection, and superior stability for longer investigation periods make them a superior candidate than other fluorescence agents.

\section{Silica-Based Nanoparticles}

Silica-based nanoparticles offer considerable advantages in nanotechnology due to their applicability for designing complex systems and cost-effectiveness. Their specific surface characteristics, porosity, and capacity for functionalization make them attractive tools for therapeutic delivery [66]. Silica nanoparticles have a large surface area covered with polar silanol groups, which are favorable for water adsorption and improve the stability of therapeutic agents. In addition, silica-based nanoparticles have ability to interact with nucleic acids, which allows their use as targeted delivery vehicles [67]. Their nanopore size and density can be tailored to achieve a constant delivery rate. Moreover, encapsulation of therapeutic agents within silica-based nanoparticles provides solid media for the delivery of agents. Pores of silica nanoparticles can be capped with various stimuli-responsive molecules to increase the rate of drug release in the targeted tissue. For instance, mesoporous silica 
nanoparticles capped with $\beta$-cyclodextrin were developed to release the encapsulated drug at the acidic tumor tissue [58]. Combination of these nanoparticles with contrast agents such as gold, silver, iron oxide, organic dyes, and quantum dots facilitates their tracking in biological systems [68]. Furthermore, these nanoparticles are used as additives in pharmaceutical production to improve the mechanical properties and the biocompatibility of the product.

\subsubsection{Lipid-Based Nanoparticles}

\section{Liposomes}

Liposomes are vesicles synthesized through the hydration of dry phospholipids. They can be prepared in distinct structure, composition, size, and flexibility with a variety of lipid molecules and further surface modification. One of the most important advantages of liposomes is their ability to fuse with cell membrane and release their contents into the cytoplasm, which makes them suitable intelligent carrier systems for targeted delivery. The simplest liposome is composed of a lipid bilayer surrounding a hollow core with a diameter of 50-1000 $\mathrm{nm}$. The therapeutic molecules can be loaded into this hollow core for delivery [69-71]. Depending on the number of bilayers, they are classified into three basic types: multilamellar, small unilamellar, and large unilamellar. Multilamellar vesicles consist of several lipid bilayers separated from one another by aqueous spaces. In contrast, unilamellar vesicles consist of a single bilayer surrounding the entrapped aqueous space. These structural properties allow them to carry both hydrophobic and hydrophilic molecules. Hydrophilic molecules can be carried in the aqueous interior of the liposome, while hydrophobic molecules can be dissolved in the lipid membrane [72]. Additionally, more than one type of drug can be loaded either within two compartments (lipid and aqueous) or several aqueous layers of multilamellar liposomes. This also allows different drug molecules to be released in sequence with dissociation of layers from the outer shell to the inner core [73]. The neutral or positively charged small liposomes have higher circulation time when compared to large, unmodified liposomes [74]. Moreover, surface modifications can be obtained by either coating it with a functionalized polymer or PEG chains that improve targeted delivery and increase their circulation time in biological systems [75]. The liposomes are investigated for a wide variety of therapeutic applications, such as cancer diagnostic and therapy, vaccines, brain-targeted drug delivery, and anti-microbial therapy [71].

\section{Exosomes}

Exosomes are naturally formed and secreted by various types of cells. They are endosome-derived extracellular vesicles with a size of 30-150 nm and usually exist in different body fluids such as saliva, blood, urine, and breast milk [76]. Exosomes are cell membrane-like lipid bilayer vesicles, which contain various substances, including RNA, DNA, glycolipids, and proteins [77,78]. Exosomes play an important role in intracellular communication by transferring various compounds in physiological mechanisms such as immune response, neural communication, antigen presentation in diseases like cancer, cardiovascular disease, diabetes, and inflammation [76,79]. Since these vesicles can be isolated from a patient's bodily fluids, allogenic exosomes have an advantage over the immune system, which can easily protect the cargo from rapid clearance and improve the drug delivery to targeted sites [80]. Therefore, studies on the potential of exosomes for the use as drug delivery carriers for cancer and autoimmune diseases, diagnostic biomarkers of cancer, and even for tissue regeneration are emerging [81,82].

\section{Solid Lipid Nanoparticles (SLN)}

Solid lipid nanoparticles (SLN) are aqueous colloidal dispersions comprised of a lipid matrix that is solid at room and body temperatures. Surfactants improve their stability, whereas the choice of lipid affects the drug delivery characteristics. The size of SLNs varies from 10 to $1000 \mathrm{~nm}$ depending on the production approach [83]. SLNs as a sub-category of lipid carriers can encapsulate very high amounts 
of lipophilic drugs as well as hydrophilic drugs and nucleic acids, making them versatile drug delivery vehicles $[84,85]$. SLNs can be decorated or loaded with various moieties, including antibodies, magnetic nanoparticles, $\mathrm{pH}$ sensitive lipids/polymers to modulate targeted delivery, and stimuli-responsive drug release $[86,87]$. They are shown to be effective carriers for cancer, pulmonary, and oral drug delivery purposes [88,89].

\subsection{Nanocrystalline Particles}

Nanocrystalline particles, or nanocrystals, are carrier-free drug particles with a crystallite size of only a few nanometers. Nanocrystal formulations are widely prepared for poorly water-soluble drugs suffering from limited bioavailability and absorption as a highly cost-effective approach. Generally, the size reduction is a suitable way to enhance the bioavailability of agents, where the dissolution velocity is the rate-limiting step. The crystalline structure leads to an increased overall surface area and thus increases dissolution velocity. This characteristic improves the solubility, which is important especially when the therapeutic index of the agent is limited due to absorption problems. Relatively, nanocrystalline particles enable the quick absorption of therapeutic agents due to their fast dissolution, offering an advantage for agents that need to work fast. By modifying the nanocrystal surface, it is possible to achieve a prolonged or targeted release, allowing for the use of therapeutic agents in low doses and decreasing side effects [90].

\section{Targeted Delivery Applications of Therapeutic Nanoparticles}

Targeted delivery refers to the successful direction of therapeutic agent and its dominant accumulation within a desirable site. For the efficient targeted delivery, the agent-loaded system should be retained in the physiological system for the preferable time, evade the immunological system, target specific cell/tissue, and release the loaded therapeutic agent [91]. Currently, targeted delivery of nanoparticles is widely studied in cancer treatment. Over $20 \%$ of the therapeutic nanoparticles already in clinics or under clinical evaluation were developed for anti-cancer applications. In addition, related research has focused on nanoparticle-mediated therapy for some other diseases, such as neurodegenerative, infectious, autoimmune, etc. diseases. The subsequent section provides up-to-date applications of therapeutic nanoparticles as targeted delivery systems in several diseases, and Table 1 summarizes the Food and Drug Administration (FDA)- and the European Medicines Agency (EMA)-approved nano-drug formulations since 2009.

Table 1. Food and Drug Administration (FDA)- and European Medicines Agency (EMA)-approved therapeutic nanoparticles since 2009.

\begin{tabular}{|c|c|c|c|c|c|c|}
\hline Nanostructure & Product & Nanoparticle Formulation & Drug & Indication(s) & Approval & Ref. \\
\hline \multirow{4}{*}{ Liposomes } & Marqibo ${ }^{\circledR}$ & $\begin{array}{l}\text { Sphingomyelin and } \\
\text { cholesterol }\end{array}$ & Vincristine sulfate & $\begin{array}{l}\text { Acute lymphoid } \\
\text { leukemia }\end{array}$ & FDA 2012 & [92] \\
\hline & Mepact ${ }^{\circledR}$ & $\begin{array}{c}\text { 1-Palmitoyl-2-oleoyl-sn- } \\
\text { glycero-3-phosphocholine } \\
\text { and 1,2-Dioleoyl-sn-glycero- } \\
\text { 3-phospho-L-serine } \\
\text { liposomes }\end{array}$ & Mifamurtide & $\begin{array}{l}\text { Non-metastasizing } \\
\text { osteosarcoma }\end{array}$ & Europe 2009 & [93] \\
\hline & Onivyde ${ }^{\circledR}$ & Nanoliposomes & Irinotecan & $\begin{array}{l}\text { Pancreatic cancer, } \\
\text { Colorectal cancer }\end{array}$ & $\begin{array}{c}\text { FDA } 2015 \\
\text { Europe } 2016\end{array}$ & [94] \\
\hline & Vyxeos ${ }^{\circledR}$ & $\begin{array}{l}\text { Distearoylphosphatidylcholine, } \\
\text { Distearoylphosphatidylglycerol, } \\
\text { Cholesterol }\end{array}$ & $\begin{array}{l}\text { Daunorubicin } \\
\text { Cytarabine }\end{array}$ & $\begin{array}{l}\text { Acute myeloid } \\
\text { leukemia }\end{array}$ & FDA 2017 & [95] \\
\hline $\begin{array}{l}\text { Lipid-based } \\
\text { (Non-liposoma) }\end{array}$ & Onpattro ${ }^{\circledR}$ & Lipid nanoparticles & $\begin{array}{l}\text { Transthyretin } \\
\text { targeted siRNA }\end{array}$ & $\begin{array}{l}\text { Transthyretin-mediated } \\
\text { amyloidosis }\end{array}$ & FDA 2018 & [96] \\
\hline
\end{tabular}


Table 1. Cont.

\begin{tabular}{|c|c|c|c|c|c|c|}
\hline Nanostructure & Product & Nanoparticle Formulation & Drug & Indication(s) & Approval & Ref. \\
\hline Polymer-based & Glatopa ${ }^{\circledR}$ & $\begin{array}{c}\text { L-glutamic acid polymer with } \\
\text { L-alanine, L-lysine, } \\
\text { and L-tyrosine (Glatiramer) }\end{array}$ & - & Multiple sclerosis & FDA 2015 & [97] \\
\hline \multirow{6}{*}{$\begin{array}{l}\text { Protein-drug } \\
\text { conjugates }\end{array}$} & Kadcyla ${ }^{\circledR}$ & Maytansine derivative, DM1 & Trastuzumab & HER2+ breast cancer & FDA 2013 & [98] \\
\hline & Abraxane $^{\circledR}$ & Albumin & Paclitaxel & $\begin{array}{l}\text { Non-small lung } \\
\text { cancer, Pancreatic } \\
\text { cancer }\end{array}$ & $\begin{array}{l}\text { FDA } 2012 \\
\text { Europe 2005, } \\
\text { FDA } 2013 \\
\text { Europe } 2008\end{array}$ & [99] \\
\hline & Krystexxa ${ }^{\circledR}$ & PEGylated uricase & Pegloticase & Gout disease & $\begin{array}{l}\text { FDA } 2010 \\
\text { Europe } 2013\end{array}$ & [100] \\
\hline & Plegridy ${ }^{\circledR}$ & PEGylated interferon $\beta-1 \mathrm{a}$ & Interferon $\beta-1 \mathrm{a}$ & Multiple sclerosis & $\begin{array}{l}\text { FDA } 2014 \\
\text { Europe } 2014\end{array}$ & [100] \\
\hline & Adynovate $^{\circledR}$ & PEGylated factor VIII & Factor VIII & Hemophilia & FDA 2015 & [101] \\
\hline & Rebinyn ${ }^{\circledR}$ & $\begin{array}{l}\text { Glycopegylated coagulation } \\
\text { factor IX }\end{array}$ & Factor IX & Hemophilia & FDA 2017 & [102] \\
\hline \multirow{3}{*}{$\begin{array}{c}\text { Metallic } \\
\text { nanoparticles }\end{array}$} & Feraheme ${ }^{\circledR}$ & $\begin{array}{l}\text { Superparamagnetic iron } \\
\text { oxide nanoparticle (SPION) } \\
\text { covered with dextran }\end{array}$ & - & $\begin{array}{l}\text { Anemia in chronic } \\
\text { kidney disease }\end{array}$ & $\begin{array}{l}\text { FDA } 2009 \\
\text { Europe } 2012\end{array}$ & [103] \\
\hline & Ferinject $^{\circledR}$ & $\begin{array}{l}\text { Nanoparticles of ferric oxide } \\
\text { core-carboxymaltose shell }\end{array}$ & - & $\begin{array}{l}\text { Iron deficiency } \\
\text { anemia in chronic } \\
\text { kidney disease }\end{array}$ & FDA 2013 & [104] \\
\hline & NanoTherm ${ }^{\circledR}$ & $\begin{array}{c}\text { Nanoparticles of } \\
\text { superparamagnetic iron } \\
\text { oxide coated with amino } \\
\text { silane }\end{array}$ & - & $\begin{array}{c}\text { Glioblastoma, } \\
\text { prostate, pancreatic } \\
\text { cancer }\end{array}$ & Europe 2009 & [105] \\
\hline \multirow{3}{*}{ Nanocrystals } & EquivaBone $^{\circledR}$ & Hydroxyapatite & - & $\begin{array}{l}\text { Osteoinductive bone } \\
\text { graft substitute }\end{array}$ & FDA 2009 & [106] \\
\hline & $\begin{array}{c}\text { Invega }{ }^{\circledR} \\
\text { Sustenna }{ }^{\circledR}\end{array}$ & Paliperidone palmitate & Paliperidone & Schizophrenia & $\begin{array}{c}\text { FDA } \\
\text { 2009/2015 } \\
\text { Europe } 2011\end{array}$ & [107] \\
\hline & Ryanodex ${ }^{\circledR}$ & Dantrolene sodium & Dantrolene & $\begin{array}{c}\text { Malignant } \\
\text { hyperthermia }\end{array}$ & FDA 2014 & [100] \\
\hline
\end{tabular}

\subsection{Cancer}

Cancer is one of the major causes of death, and chemotherapy is widely used as a treatment approach for various cancer types. However, chemotherapeutic agents suffer from the lack of aqueous solubility, exhibit dose-dependent toxicity, and their tumor specificity is inadequate [108]. Multidrug resistance is another challenge in chemotherapy, which mainly occurs due to increased efflux pumps that are responsible for the export of anti-cancer agents from cell membrane [109].

Recent developments of nano-delivery systems overcome these limitations targeting directly the cancer cell, delivering the agent at a controlled rate, and optimizing the therapeutic efficacy [110]. A variety of nanoparticles has been developed for delivery of anti-cancer agents, and two major mechanisms are used to deliver them at the tumor site: Passive targeting and active targeting [111]. Passive targeting is based on the accumulation of therapeutic agent in the tumors due to their distinctive features compared to normal tissues. Tumors have leaky vasculature and defective lymphatic drainage promoting the delivery and retention of therapeutic nanoparticles, commonly referred to as the EPR effect [112]. Nonetheless, nanoparticles encounter several obstacles during passive targeting. Mucosal barriers or non-specific uptake of particles on the way to their target limit their efficiency. In contrast, active targeting achieves selective recognition of the targeted cells by carrying ligands at the surface of nanoparticles that bind to receptors or stimuli-based carriers $[113,114]$.

Currently, the majority of FDA-approved therapeutic nanoparticles are developed as a re-formulation of chemotherapeutic drugs combinations with polymeric nanoparticles. The first nano-drug for cancer treatment was a PEGylated liposomal formulation of doxorubicin (Doxil ${ }^{\circledR}$, Caelyx $\left.{ }^{\circledR}\right)$. Doxil is formulated with sterically stabilized liposomes composed of phospholipids, cholesterol, and a lipopolymer (PEG) to achieve extended circulation time and eliminate RES. It is less than $120 \mathrm{~nm}$ and thus takes the advantage of EPR in accumulation in the tumor and in resulting in decreased cardiotoxicity [115]. Another example of liposomal drug formulation is Marqibo ${ }^{\circledR}$, 
which is approved by the FDA for the treatment of acute lymphocytic leukemia in adults [92]. The liposomal formulation of Marqibo ${ }^{\circledR}$ (Vincristine sulfate) is generated from sphingomyelin and cholesterol, which greatly improves the circulation time and expedite dose intensification as compared to standard Vincristine [116]. There are several lipid-based formulations under clinical trials as well $[117,118]$. For instance, one of the first line cancer chemotherapy agents, cisplatin, is formulated in soy phosphatidylcholine (SPC-3), cholesterol, dipalmitoyl phosphatidyl glycerol (DPPG), and methoxy-PEG-distearoyl phosphatidyl ethanolamine (mPEG2000-DSPE) under the brand name Lipoplatin ${ }^{\circledR}$ (Regulon, Inc.). Lipoplatin ${ }^{\circledR}$ pre-clinical trials revealed less nephrotoxicity in comparison to the conventional drug. Consequently, The European Medicines Agency (EMA) announced Lipoplatin ${ }^{\circledR}$ as an orphan drug for the treatment of pancreatic adenocarcinoma, breast cancer, and advanced gastric cancer [119-122].

Drug conjugates are arranged to facilitate either the targeted delivery of cytotoxic drugs to tumor cells or decreased systemic cytotoxicity of the drug [123]. The FDA approved such an antibody-drug conjugate namely Kadcyla ${ }^{\circledR}$ for the treatment of HER2+ breast cancer. The drug Kadcyla ${ }^{\circledR}$ is formed by covalent conjugation of maytansine derivative DM1 to transtuzumab (known as Herceptin $\left.{ }^{\circledR}\right)$ through the lysine residues of the antibody [124,125]. Thus, DM1 is delivered to HER2+ breast cancer cells through transtuzumab recognition of HER receptor, and internalized DM1 triggers apoptosis. The albumin-conjugated nanoparticle version of the anti-cancer drug paclitaxel (Abraxane ${ }^{\circledR}$ ) or a re-formulation of the rapamycin drug with micellar nanoparticles (Rapamune ${ }^{\circledR}$ ) are other FDA-approved therapeutic nanoparticles with lower side effects and improved therapeutic indices over their conventional counterparts [126]. Table 2 summarizes the therapeutic nanoparticles evaluated in the pre-clinical or clinical trials.

Table 2. Therapeutic nanoparticles under pre-clinical or clinical evaluation.

\begin{tabular}{|c|c|c|c|c|}
\hline Nanostructure & Nanoparticle & Conjugated Drug & Evaluation & Ref \\
\hline \multirow{2}{*}{ Dendrimer } & $\begin{array}{l}\text { Polyethylene glycol } \\
\text { (PEG)-platinum }\end{array}$ & $\alpha$-cyclodextrin & pre-clinical & [127] \\
\hline & Polyamidoamine dendrimer & $N$-acetyl-cysteine & clinical/phase I & [128] \\
\hline \multirow{2}{*}{ Micelle } & $\begin{array}{l}\text { Polypropylene sulfide-PEG- } \\
\text { serine-folic acid } \\
\text { zinc phtalocyanine }\end{array}$ & doxorubicin & pre-clinical & [129] \\
\hline & $\begin{array}{l}\text { PEG-polyaspartate } \\
\text { polymeric micelle }\end{array}$ & paclitaxel & clinical/phase III & [130] \\
\hline Carbon nanotube & PEGylated single walled CNT & $\begin{array}{l}\text { epidermal growth } \\
\text { factor (EGF), cisplatin }\end{array}$ & pre-clinical & [131] \\
\hline \multirow{7}{*}{$\begin{array}{c}\text { Metallic } \\
\text { nanoparticles }\end{array}$} & $\begin{array}{l}\text { Hollow mesoporous copper } \\
\text { sulfide nanoparticle with } \\
\text { iron oxides }\end{array}$ & doxorubicin & pre-clinical & [132] \\
\hline & $\begin{array}{l}\text { Hollow mesoporous copper } \\
\text { sulfide nanoparticle with } \\
\text { hyaluronic acid }\end{array}$ & doxorubicin & pre-clinical & [133] \\
\hline & PEGylated MoS nanosheets & & pre-clinical & [134] \\
\hline & $\begin{array}{l}\text { Azo-functionalized magnetite } \\
\text { nanoparticles }\end{array}$ & doxorubicin & pre-clinical & [135] \\
\hline & $\begin{array}{l}\text { PEGylated gold nanorods } \\
\text { (AuNR) }\end{array}$ & doxorubicin & pre-clinical & [136] \\
\hline & $\begin{array}{c}\text { Iron oxide magnetic } \\
\text { silica-gold nanoparticles }\end{array}$ & & clinical/phase I & [137] \\
\hline & PEGylated gold nanorod & aptamer & pre-clinical & [138] \\
\hline
\end{tabular}


Table 2. Cont

\begin{tabular}{|c|c|c|c|c|}
\hline Nanostructure & Nanoparticle & Conjugated Drug & Evaluation & $\overline{\text { Ref }}$ \\
\hline \multirow{5}{*}{$\begin{array}{l}\text { Silica based } \\
\text { nanoparticles }\end{array}$} & $\begin{array}{l}\text { Peptide-functionalized } \\
\text { mesoporous silica }\end{array}$ & $\begin{array}{l}\text { lactobionic acid, } \\
\text { doxorubicin }\end{array}$ & pre-clinical & [139] \\
\hline & Transferrin mesoporous silica & doxorubicin & pre-clinical & [140] \\
\hline & PEGylated mesoporous silica & $\begin{array}{l}\text { amino- } \beta \text {-cyclodextrin, } \\
\text { doxorubicin }\end{array}$ & pre-clinical & [141] \\
\hline & mesoporous silica & $\begin{array}{c}\text { cytochrome } \mathrm{C} \\
\text { conjugated lactobionic } \\
\text { acid-doxorubicin }\end{array}$ & pre-clinical & [142] \\
\hline & $\begin{array}{c}\text { Hydroxyapatite } \\
\text { nano-crystalline } \\
\text { nano-structured silica gel }\end{array}$ & & clinical/phase 0 & [143] \\
\hline \multirow{2}{*}{ Nanodiamonds } & PEGylated nanodiamonds & doxorubicin & pre-clinical & {$[144]$} \\
\hline & PEGylated nanodiamonds & irinotecan, curcumin & pre-clinical & {$[145]$} \\
\hline
\end{tabular}

\subsection{Infectious Diseases}

The major therapeutic approach for infectious disease is the use of anti-microbial drugs. However, pathogens can become resistant, where anti-microbial drugs become therapeutically insufficient. In that case, administration dose and frequency are increased, which results in increased side effects and toxicity. Besides, many pathogens are located intracellularly in an active or latent state, which prevents the access of anti-microbial drugs $[146,147]$. The use of nano-delivery systems promises to overcome such limitations. Therefore, there is a growing interest to generate nanotechnology-based formulations against various pathogens, such as bacteria, viruses, fungi, or parasites.

Application of nano-delivery for the treatment of infectious diseases includes both polymer-based and non-polymeric nanoparticles, as well as liposomes that improve the anti-microbial activity of drugs [148]. Ciprofloxacin is a broad-spectrum antibiotic prescribed for lung infections. Lipoquin ${ }^{\mathrm{TM}}$, the liposome formulation of ciprofloxacin, is designed as an inhaled formula for sustained release of up to $24 \mathrm{~h}$ and thus eliminated the systemic effects of the high-dose antibiotic [149]. Similarly, the anti-fungal liposomal carrier Ambisome ${ }^{\circledR}$ (amphotericin B) is designed to reduce associated toxicity of amphotericin B [150]. Due to its low systemic toxicity, liposomal amphotericin B can be used for highly immunocompromised patients with HIV infection or disseminated histoplasmosis [151].

Nanoparticles can also be fabricated into anti-viral drugs. Virosomal vaccines are the carriers of viral adjuvants such as viral glycoproteins, toll-like receptor, or protein fractions. Such vaccines, e.g., Inflexal ${ }^{\circledR} \mathrm{V}$ for hepatitis-A and Epaxal ${ }^{\circledR}$ for influenza, are already used in clinics for therapeutic purposes [152]. Virosomal vaccine formulations are also being investigated, for instance in clinical trials for Ebola virus (EBOV). That approach creates safer viral vaccines and induces strong and long-lasting immune response.

Anti-microbial nano-drugs are also used to decorate medical devices to eliminate biofilm formation [153], such as AgNPs in central venous catheters [154]. Furthermore, there are some nanoparticles used in diagnosis or as medical devices like Verigene ${ }^{\circledR}$, Silverline ${ }^{\circledR}$, Acticoat ${ }^{\mathrm{TM}}$, or Endorem ${ }^{\mathrm{TM}}$ SPIONs $[105,155,156]$.

A short list of therapeutic nanoparticles against resistant strains and some nano-delivery systems used for prevention and treatment against bacterial infection can be found in Table 3 . 
Table 3. Therapeutic nanoparticles and nano-delivery systems for the prevention and treatment of bacterial infections.

\begin{tabular}{|c|c|c|c|c|}
\hline Pathogen & Nanoparticle & Conjugated Drug & Evaluation & Ref \\
\hline C. Albicans & Metallic nanoparticle (AgNP) & Fluconazole & In vitro & [157] \\
\hline E. Coli & Metallic nanoparticle (AuNP and AgNP) & Ampicillin & In vitro & [158] \\
\hline E. Coli & Metallic nanoparticle (ZnO-PEI) & Tetracycline & In vitro & [159] \\
\hline \multirow{2}{*}{ Enterococci } & Metallic nanoparticle (AuNP) & \multirow{2}{*}{ Vancomycin } & In vitro & [160] \\
\hline & Liposome & & In vitro & [161] \\
\hline HIV-infected cells & Polymeric nanoparticle (Micelle) & Nelfinavir, saquinavir & In vitro & [162] \\
\hline P. Aeruginosa & Liposome & Polymyxin B & In vitro & [163] \\
\hline P. Aeruginosa & Metallic nanoparticle (AuNP) & Ampicillin & In vitro & [158] \\
\hline Plasmodium sp. & Liposome & Chloroquine & In vitro & [164] \\
\hline \multirow{7}{*}{ S. Aureus } & Chitosan NP & \multirow{2}{*}{ Vancomycin } & In vitro & [165] \\
\hline & Metallic nanoparticle (AuNP) & & In vitro & [166] \\
\hline & Polymeric nanoparticle (PLA NP) & \multirow{2}{*}{ Penicillin } & In vitro & [167] \\
\hline & Silica nanoparticle & & In vitro & [168] \\
\hline & Chitosan NP & Streptomycin & In vitro & [169] \\
\hline & Liposome & $\beta$-Lactam, penicillin & In vitro & [170] \\
\hline & Metallic nanoparticle (AuNP and AgNP) & Ampicillin & In vitro & {$[158,166]$} \\
\hline
\end{tabular}

\subsection{Autoimmune Diseases}

Rheumatoid arthritis (RA) and acquired immunodeficiency syndrome (AIDS) are the main two diseases being treated using nano-delivery systems.

RA is one of the common and severe autoimmune diseases affecting almost $1 \%$ of the world's population. Despite the cause being unknown, the complex interaction between immune mediators is likely responsible for the bone and cartilage destruction. New therapy approaches are able to improve the quality of the patient's life; however, a restricted administration route and the requirement of repetitive long-term treatment result in systemic adverse effects [171]. Nanoparticle systems are promising for the delivery of therapeutic agents particularly to target inflamed tissue (synovial membrane), thereby preventing systemic and undesired effects. Certolizumab pegol (CZP) is a TNF- $\alpha$ inhibitor widely used in clinic [161,172]. Nano-formulation of CZP with PEG increases its half-life to $\sim 14$ days, and clinical trials have shown promising results for the long-term treatment on RA patients [173]. Targeting inflamed tissues by using stand-alone C60 fullerenes (non-drug loaded) showed promising results in RA treatment by reducing synovitis and alleviated bone resorption and destruction [174].

Acquired immunodeficiency syndrome (AIDS) is another autoimmune disease lacking treatment. Current clinical therapy is called highly active anti-retroviral treatment (HAART), which consists of a combination of at least three anti-HIV medications suppressing human immunodeficiency virus (HIV) replication. Although this therapeutic approach has contributed to a decreased mortality rate, it is not fully effective [175]. Recently, nano-delivery systems are under development based on polymeric and liposomal nano-carriers to provide a target-specific and sustained release formulation of anti-HIV drugs. The goal is to improve efficiency of anti-HIV treatment and limit systemic side effects [176]. For instance, efavirenz is loaded into poly(propyleneimine) dendrimers (TuPPI), which are decorated with Tuftsin. Final TuPPI particles were able to recognize mononuclear phagocytic cells through Tuftsin and resulted in significantly higher uptake in HIV infected macrophages compared to uninfected cells [177]. Additional examples of nanoparticle drug formulations for AIDS therapy are summarized in Table 4. 
Table 4. Therapeutic nanoparticle drug formulations for the treatment of AIDS disease.

\begin{tabular}{|c|c|c|c|c|}
\hline Nanostructure & Nanoparticle & Conjugated Drug & Evaluation & Ref \\
\hline \multirow{7}{*}{$\begin{array}{c}\text { Polymeric } \\
\text { nanoparticle }\end{array}$} & $\begin{array}{c}\text { Poly(hexylcyanoacrylate) } \\
\text { nanoparticles }\end{array}$ & Zidovudine & Pre-clinical & [178] \\
\hline & $\begin{array}{c}\text { Poly(isohexyl cyanate) } \\
\text { nanoparticles }\end{array}$ & Zidovudine & Pre-clinical & [179] \\
\hline & $\begin{array}{l}\text { Poly(propyleneimine) } \\
\text { dendrimers }\end{array}$ & Efavirenz & In vitro & [177] \\
\hline & PPI dendrimer & Efavirenz & In vitro & [180] \\
\hline & PLGA nanoparticles & $\begin{array}{l}\text { Ritonavir, Lopinavir, } \\
\text { Efavirenz }\end{array}$ & Pre-clinical & {$[181,182]$} \\
\hline & $\begin{array}{c}\text { PBCA and MMA-SPM } \\
\text { nanoparticles }\end{array}$ & $\begin{array}{l}\text { Stavudine, Zidovudine, } \\
\text { Lamivudine }\end{array}$ & In vitro & [183] \\
\hline & Poly(epsilon-caprolactone) & Saquinavir & In vitro & [184] \\
\hline Liposome & $\begin{array}{l}\text { Mannosylated and } \\
\text { galactosylated liposomes }\end{array}$ & Stavudine & In vitro & [185] \\
\hline
\end{tabular}

\subsection{Cardiovascular Diseases}

Cardiovascular disease (CVD) affects the cardiovascular system, vascular systems of the brain and kidney, and peripheral arteries. Despite many novel therapeutic strategies such as gene delivery and cell transplantation, heart failure is still a leading cause of mortality worldwide [186]. Utilization of nanoparticle-based formulations to treat cardiovascular diseases is mostly focused on targeted delivery and increasing bioavailability for vascular restenosis.

As a nanoparticle drug for restenosis, liposomes formed by phosphatidylcholine and cholesterol were loaded with small drug sirolimus and coated with chitosan. The resulted liposomal sirolimus is shown to significantly inhibit vascular restenosis [187]. Another drug, carvedilol is a $\beta$-blocker widely used for the treatment of hypertension, myocardial infarction (MI), congestive heart failure, and post-MI left ventricular dysfunction. However, its low water solubility and extensive pre-systemic metabolism limit its bioavailability. The niosome-based nanoparticle formulation encapsulating carvedilol reached 1.7-2.3-fold higher plasma concentrations compared to the free drug, resulting in enhanced bioavailability and improved therapeutic effect [188]. Similarly, resveratrol is a cardio-protective polyphenol with low bioavailability and water-solubility. Its nano-formulations both as solid lipid nanoparticle and liposome showed enhanced oral bioavailability and controlled release [189].

Angiogenic therapy of myocardial ischemia with vascular endothelial growth factor (VEGF) is a convenient approach to overcome hypoxia-dependent side effects. Polymeric particles loaded with VEGF have been proposed as a promising system to improve vasculogenesis and tissue remodeling in an acute myocardial ischemic model $[190,191]$. A targeting nano-delivery system in atherosclerosis is also achieved to visualize and treat atherosclerotic lesions by using magneto-fluorescent nanoparticles or ligand-binding polymeric micelles [192].

\subsection{Neurodegenerative Diseases}

Neurodegenerative diseases (NDs) are characterized via the progressive loss of the function of neurons, which subsequently causes neuronal death. Patients with NDs, such as Alzheimer's disease (AD), Parkinson's disease (PD), and multiple sclerosis (MS), have symptoms related to movement, memory, and dementia as a result of gradual loss of neurons. Although significant progress has been achieved in the treatment of NDs, the therapeutic strategies are limited due to the restrictive structure of the blood-brain barrier (BBB). The BBB is a highly selective semipermeable membrane, which separates the circulating blood from the brain and prevents the passage of the majority of the molecules in circulation so that central nervous system homeostasis is maintained [193]. Due to the highly selective nature of the BBB, only a small portion of therapeutic drugs can reach the brain. 
Therefore, high doses are required leading to adverse systemic effects. Nanoparticle-based therapeutic approaches in NDs mainly focus on targeted delivery and sustained local release of therapeutic agents into the affected area of the brain after crossing the BBB [194,195].

The aggregation of the amyloid- $\beta(\mathrm{A} \beta)$ peptide into amyloid plaques is the main pathological feature of $\mathrm{AD}$, and current treatments include cholinesterase inhibitors (donepezil, rivastigmine, galantamine) and N-methyl-D-aspartate (NMDA) receptor antagonists (memantine) [196]. Reformulation of clinically used drugs with polymeric nanoparticles, non-polymeric quantum dots, and lipid-based nanoparticles enables their passage through BBB and reduces the side effects compared to free drug administration [197-202]. Concerning nano-delivery systems, there are also other attempts to cross the $\mathrm{BBB}$ and to reduce $\mathrm{A} \beta$ aggregates by using several neuroprotective compounds like metal chelators and various NMDA antagonists of anti-amyloids [203,204].

Parkinson's disease (PD) is another type of neurodegenerative disease characterized by the selective degeneration of dopaminergic neurons and by the existence of $\alpha$-synuclein as well as protein inclusions in neurons named Lewy bodies [205]. Dopamine replacement therapies are presently the most used strategy for PD treatment, since this class of drugs can help to improve the symptoms in motor neurons and is able to slow down the progression of the disease. However, the effect of these drugs on behavior and cognition is still in debate [206]. Recent research activities in nano-delivery focused on the development of therapeutic nanoparticles based on different strategies. Targeted delivery of dopamine using polymeric nanoparticles or liposomes is one of the nanoparticle-based therapeutic approaches in PD treatment [207]. Several studies use various drugs (Ropinirole, Bromocriptine, Mitoapocynin, Apomorphine) encapsulated with liposomes or polymeric nanoparticles in order to improve sustained release of drugs and to reduce undesired effects of conventional PD therapy [208-210]. Anti-inflammatory strategies are also developed by using polymeric nanoparticles or PEGylated liposomes to prevent neuronal cell death in PD [211-213]. As a neurotrophic strategy, PEGylated nanoparticles loaded with h-GDNF (glial cell-derived neurotrophic factor) improve locomotor activity and decrease the loss of dopaminergic neurons, which results in enhanced dopamine levels [214,215]. Moreover, polymer-based biodegradable nanoparticles have been engineered as cell therapeutics allowing stem cells to repair damaged nerves [216]. On the other hand, several groups proposed therapeutic nano-systems for the delivery of genetic material (DNA, RNA, and oligonucleotides) to inhibit faulty gene expression or synthesize therapeutic proteins in affected cells [217]. Although significant improvement in clinical symptoms is observed in advanced PD patients who underwent gene therapy, this approach is still a contradictive issue because of the heterogenic pathology of PD [218].

Despite many research articles on the development of novel therapeutic nanoparticles published for AD and PD, only few approaches have been reported for other neurodegenerative diseases, like amyotrophic lateral sclerosis (ALS) and multiple sclerosis (MS). ALS is a progressive neurodegenerative disease affecting motor neurons responsible for controlling voluntary muscle movements (chewing, walking, and talking) in the brain and spinal cord. Clinically, progressive muscle weakness results in death due to respiratory failure. To date, the only agent approved for treatment of ALS is Riluzole. Loading Riluzole in solid lipid nanoparticles promotes the delivery of the drug to the CNS (central nervous system), and $\mathrm{pH}$-based controlled release is achieved with lower random biodistribution in organs such as the liver, spleen, heart, kidneys, and lung [219,220]. MS is characterized by the destruction of the protective coating (myelin sheath) on nerves of the central nervous system, which causes a faulty relay of instructions from the brain to the body. The conjugation of a glutamate receptor antagonist with a non-polymeric fullerene derivative nanoparticle is able to rescue the clinical progression of chronic MS in an in vivo model [221]. In 2015, Glatopa ${ }^{\circledR}$ was approved by the FDA as the first generic drug, which is derived from the only therapeutic peptide, also approved by the FDA for the treatment of MS, glatiramer acetate (also known as the Copaxone ${ }^{\circledR}$ ) [222]. Glatiramer acetate is a random copolymer and a synthetic peptide composed of 1-lysine, l-alanine, l-glutamic acid, 
and l-tyrosine, which could suppress inflammatory responses by blocking MHC-II and changes the population of T-cell [102].

\subsection{Ocular Diseases}

Current ocular therapies taking advantage of nanomedicine can be enumerable as mydriatics or cycloplegics miotics, infection, and inflammatory, as well as diagnostic and surgical, adjuvants. However, several barriers, including the mucoaqueous tear layer, corneal epithelium, and the blood-retina barrier, make the eye impermeable for most therapeutic agents [223]. Targeted nano-delivery systems offer advantages in ocular disease therapy by lowering eye irritation and enhancing the bioavailability by providing a route of entry to the eye [224]. The most widely used nano-delivery systems are polymeric nanoparticles and liposomes developed for targeting the drugs to the right compartment of the eye, initially by increasing residence time on the tear film and enhancing corneal permeability $[225,226]$. Nano-formulation of the drug pranoprofen with the polymer PLGA (poly (lactic-co-glycolic acid) significantly enhanced its ophthalmic delivery and local anti-inflammatory and analgesic effects of the drug [227]. Similarly, chitosan-based polymeric nanoparticles encapsulating cefuroxime, diclofenac, or dexamethasone improved ocular bioavailability of the drugs [228]. These nanoparticles are able to interact with ocular surface while protecting the drug from metabolic degradation and extending pre-corneal residence [229]. Similarly, lipid-based nanoparticles loaded with brimonidine were used to treat an ophthalmic disease, glaucoma [230-232]. Immunologic graft rejection is a challenge in corneal transplantation. PLGA- or PEG-based polymeric formulations of dexamethasone and curcumin prevent the rejection of corneal graft due to the sustained release of the corticosteroids $[233,234]$.

\subsection{Pulmonary Diseases}

Pulmonary lung diseases include asthma, chronic obstructive pulmonary disease (COPD), cystic fibrosis, pulmonary tuberculosis, and idiopathic pulmonary fibrosis (IPF) [235]. These diseases are often fatal, and there is no effective treatment for completely restoring lung function. Conventional therapeutics are applied either systemically or locally to the lungs in the form of inhalers. Inhalation of free drugs, where the active molecules are in aerosol form, can lead to burst release and thus high lung toxicity. Moreover, the size of the aerosol limits the efficiency of the drug, as molecules $>5 \mu \mathrm{m}$ cannot pass the upper respiratory tract, particles between 1-5 $\mu \mathrm{m}$ mostly settle at the lower respiratory tract, and particles $<1 \mu \mathrm{m}$ stay suspended in air and exhaled. Nanoparticle-based delivery systems enable enhanced bioavailability, controlled release, and decreased dosage and application frequency. For the development of nanomedicine inhalation formulations, natural polymeric nanoparticles such as gelatin, chitosan, and alginate, as well as synthetic polymers like poloxamer, PLGA, and PEG, are widely used [236,237]. Moreover, polyamidoamine (PAMAM) dendrimers assembled with anti-asthma beclometasone dipropionate (BDP) were effectively used for pulmonary inhalation [238]. Besides, lipid-, polysaccharide-, or polymer-based nanoparticles and metallic or carbon-based nanoparticles were utilized for vaccine delivery or pulmonary immune hemostasis [239].

\subsection{Regenerative Therapy}

Regenerative therapy focuses on the design and application of biocompatible materials, which can enhance the repair and regeneration of tissues by making use of their natural cellular mechanisms. Stem cell-based therapy is one strategy for promoting tissue's natural repair or regeneration mechanism.

Over the years, there has been increased interest in the development and direct administration of therapeutic nanoparticles to promote bone regeneration [240]. The most commonly used nano-delivery systems for bone regeneration are synthetic (PLA or PLGA) or natural polymers (collagen, gelatin, albumin, and chitosan). Besides the polymeric ones, various formulations of non-polymeric nanoparticles (silica-based, metallic) have also been used as nano-delivery systems for bone regeneration. For example, calcium phosphate-based non-polymeric nanoparticles are mostly used due to their 
similarities to human bone [241-243]. Delivering several growth factors is one of the nanoparticle-based therapeutic strategies based on the stimulation of osteoblasts for bone formation [244-247]. Moreover, nano-delivery of synthetic molecules is used as another therapeutic strategy in bone tissue, which could suppress the bone-resorbing cells, the osteoclasts. The bisphosphonate drugs promote osteoclasts apoptosis and are thus widely used for osteoporosis treatment. Several types of polymeric or non-polymeric metallic nanoparticles have been used to deliver bisphosphonate drugs [248,249].

Implantations of bone-graft substitutes stimulating mineralization are an alternative and effective approach for bone and dental tissue regeneration. EquivaBone ${ }^{\circledR}$ is a nanotherapeutic that consists of hydroxyapatite, carboxymethyl cellulose, and demineralized bone matrix. EquivaBone ${ }^{\circledR}$ is used as an osteoinductive bone graft substitute and was approved by FDA in 2009 [250].

Another strategy for the use of therapeutic nanoparticles in bone tissue is reducing inflammation, particularly in the case of large wounds. Synthetic or natural polymeric nanoparticles loaded with anti-inflammatory agents are delivered into the infected area, which could inhibit both inflammation and osteoblast resorption [251,252].

\section{Limitations and Disadvantages of Therapeutic Nanoparticles}

Utilization of nanoparticles provides promising results for the treatment of a large variety of diseases from cancer to glaucoma. Nanomedical approaches based on nanoparticle technologies, unfortunately, come with some limitations and disadvantages. Nanoparticle toxicity, eluding from the phagocytic system, refraining from the physiological barrier, and generating immune response are only some of the issues that should be taken into consideration carefully while using them in living organisms [253].

In vitro and in vivo studies showed that there is a relation between the size and toxicity of therapeutic nanoparticles. As nanoparticle sizes get smaller, dispersion to the nucleus steadily increases, which in return can cause intrinsic toxicity both at cellular and systemic level [254,255]. Another obstacle with smaller nanoparticles is their aggregation tendency. For instance, smaller size of micelles, dendrimers, and QDs are inclined to aggregation that results in poor biodistribution [256-259]. Although surface functionalization with PEG is a very effective method for reducing accumulation in non-target organs, these nanoparticles are often referred to as "stealth" nanoparticles because they can elude from the phagocytic system and may provoke cellular toxicity [260].

Therapeutic nanoparticles combined with drugs currently used in medical applications provide various features to the drug and increase the efficiency of the treatment. However, Manzoor et al. found that drug concentration and penetration into the tumor areas might be limited with nanoparticle-based drug delivery systems due to the heterogeneities of vascular permeability. In order to overcome the problem, they suggested a controlled delivery by using drug-loaded liposomes that are being triggered by local heat for drug release in vitro [261].

QDs are another type of contradictive nanoparticles for medical applications. As mentioned above, QDs have characteristic properties for fluorescent emission; thus, they are widely used for imaging applications. Beside their benefits during diagnosis of the disease, QDs have non-negligible disadvantages such as high intrinsic cytotoxicity. Research related to cadmium-based quantum dots showed that there is leakage of metal ions in QDs, resulting in high toxicity in hepatocyte cultures [262-264]. Shao et al. showed that effects of QDs could differ depending on the coating types as liposome or polymer. Another research indicated that quantum dot-lipid complex (QD-LC) has little effect on normal human hepatic cells and selectively kills cancer cells in a dose- and time-dependent manner in vivo. Furthermore, QD-LC nanoparticles trigger reactive oxygen species (ROS)-mediated apoptotic c-Jun N-terminal kinase (JNK) pathway in human liver cancer cells [265]. 


\section{Conclusions}

During the last decade, development of nanoparticle-based therapeutic agents has been extensively studied, and nano-delivery systems are the area of prime importance for specifically targeting the desired area in the treatment of many diseases.

Currently, the majority of nanoparticles used for the targeting delivery approach are made of polymers or lipids. Even though polymeric nanoparticles demonstrate great advantages in disease therapy, they also present disadvantages such as difficulties in scaling up, usage of organic solvents in their fabrication process, biocompatibility, cytotoxicity, and immunogenicity. On the other hand, lipid-based nanoparticles exhibit the ability to cross hard-to-reach sites, even without any surface functionalization, because of their similarity to cell membrane. Thus, lipid-based nano-delivery systems are considered as the next generation of therapeutics.

As of today, therapeutic nanoparticles are mostly developed for the treatment or prevention of only one disease. However, researchers started to combine various drug molecules as well as various types of nanoparticles, thereby, the future of therapeutic nanoparticles is guided to the direction of multi-therapeutic nanoparticles to be designed for the treatment of more than one disease.

Although nanoparticle-based delivery systems contribute significantly to the targeted therapy with improved efficiency, reduced side effects, and better bioavailability, we still know very little about the metabolism, clearance, and toxicity of nanoparticles. To date, most of the published studies demonstrate the encapsulation of clinical drugs with nanoparticles. However, the studies on other therapeutics, like genes, enzymes, or DNA/RNA, are still limited. The significance of published data is often approved with patents; however, a few of them can pass the trials and become commercially available in the market. This suggests that additional studies are required about the formulation, fabrication, and toxicity of nanoparticles. Moreover, cost of nanomedicine and manufacturing at larger scale is another important issue needing to be addressed. The lack of financial input or the poor cost-benefit balance prevents the progress of therapeutics from their inception to the market. Consequently, understanding the characteristics of nanoparticles and their interactions with their biological environment, like their targeting receptors or mechanisms of action in disease pathophysiology, will enable us to overcome limitations and to establish novel strategies for the treatment, prevention, and diagnosis in many diseases, particularly untreatable ones.

Nanomedicine will be the future of medicine, and nanoparticle-based therapeutics lies at the heart of it. However, a long ground should be gained before prosperity. Most importantly, long-term safety/toxicity of the nanoparticles should be investigated. Meanwhile, the discoveries on disease mechanisms and new drugs will lead to ways of placing more efficient and safer nanoparticle-based therapeutics in treatment regimens.

Author Contributions: A.A.Y.; writing-original draft preparation, S.C.; M.Z.; A.K.; review and editing, O.K.; supervision. All authors have read and agreed to the published version of the manuscript.

Funding: This work was supported by Sabanci University, Internal Grant for Research Project No: I.A.SN-17-01698.

Conflicts of Interest: The authors declare that there is no conflict of interest.

\section{References}

1. Chandrasekhar, S.; Iyer, L.K.; Panchal, J.P.; Topp, E.M.; Cannon, J.B.; Ranade, V.V. Microarrays and microneedle arrays for delivery of peptides, proteins, vaccines and other applications. Expert Opin. Drug Deliv. 2013, 10, 1155-1170. [CrossRef]

2. Rabl, P.; Kolkowitz, S.J.; Koppens, F.H.L.; Harris, J.G.E.; Zoller, P.; Lukin, M.D. A quantum spin transducer based on nanoelectromechanical resonator arrays. Nat. Phys. 2010, 6, 602-608. [CrossRef]

3. Shabnashmi, P.S.; Naga Kani, S.; Vithya, V.; Vijaya Lakshmi, B.; Jasmine, R. Therapeutic applications of Nanorobots-Respirocytes and Microbivores. J. Chem. Pharm. Res. 2016, 8, 605-609. 
4. Kadam, R.S.; Bourne, D.W.; Kompella, U.B. Nano-advantage in enhanced drug delivery with biodegradable nanoparticles: Contribution of reduced clearance. Drug Metab. Dispos 2012, 40, 1380-1388. [CrossRef] [PubMed]

5. Jahan, S.T.; Sadat, S.M.A.; Walliser, M.; Haddadi, A. Targeted Therapeutic Nanoparticles: An Immense Promise to Fight against Cancer. J. Drug Deliv. 2017, 2017, 9090325. [CrossRef] [PubMed]

6. Shreffler, J.W.; Pullan, J.E.; Dailey, K.M.; Mallik, S.; Brooks, A.E. Overcoming Hurdles in Nanoparticle Clinical Translation: The Influence of Experimental Design and Surface Modification. Int. J. Mol. Sci. 2019, 20, 6056. [CrossRef] [PubMed]

7. Ernsting, M.J.; Murakami, M.; Roy, A.; Li, S.-D. Factors controlling the pharmacokinetics, biodistribution and intratumoral penetration of nanoparticles. J. Control. Release 2013, 172, 782-794. [CrossRef]

8. Wu, W.; Luo, L.; Wang, Y.; Wu, Q.; Dai, H.B.; Li, J.S.; Durkan, C.; Wang, N.; Wang, G.X. Endogenous $\mathrm{pH}$-responsive nanoparticles with programmable size changes for targeted tumor therapy and imaging applications. Theranostics 2018, 8, 3038-3058. [CrossRef]

9. Bhatia, S. Nanoparticles Types, Classification, Characterization, Fabrication Methods and Drug Delivery Applications. In Natural Polymer Drug Delivery Systems: Nanoparticles, Plants, and Algae; Bhatia, S., Ed.; Springer International Publishing: Cham, Switzerland, 2016; pp. 33-93. [CrossRef]

10. Nakamura, Y.; Mochida, A.; Choyke, P.L.; Kobayashi, H. Nanodrug Delivery: Is the Enhanced Permeability and Retention Effect Sufficient for Curing Cancer? Bioconjug Chem. 2016, 27, 2225-2238. [CrossRef]

11. Fang, J.; Nakamura, H.; Maeda, H. The EPR effect: Unique features of tumor blood vessels for drug delivery, factors involved, and limitations and augmentation of the effect. Adv. Drug Deliv. Rev. 2011, 63, 136-151. [CrossRef]

12. Yu, M.K.; Park, J.; Jon, S. Targeting Strategies for Multifunctional Nanoparticles in Cancer Imaging and Therapy. Theranostics 2012, 2, 3-44. [CrossRef] [PubMed]

13. Zhang, S.; Li, J.; Lykotrafitis, G.; Bao, G.; Suresh, S. Size-Dependent Endocytosis of Nanoparticles. Adv. Mater. 2009, 21, 419-424. [CrossRef] [PubMed]

14. Gratton, S.E.; Ropp, P.A.; Pohlhaus, P.D.; Luft, J.C.; Madden, V.J.; Napier, M.E.; DeSimone, J.M. The effect of particle design on cellular internalization pathways. Proc. Natl. Acad. Sci. USA 2008, 105, 11613-11618. [CrossRef] [PubMed]

15. Wang, C.; Zhao, T.; Li, Y.; Huang, G.; White, M.A.; Gao, J. Investigation of endosome and lysosome biology by ultra $\mathrm{pH}$-sensitive nanoprobes. Adv. Drug Deliv. Rev. 2017, 113, 87-96. [CrossRef]

16. Casey, J.R.; Grinstein, S.; Orlowski, J. Sensors and regulators of intracellular pH. Nat. Rev. Mol. Cell Biol. 2010, 11, 50-61. [CrossRef]

17. Walkey, C.D.; Olsen, J.B.; Guo, H.; Emili, A.; Chan, W.C. Nanoparticle size and surface chemistry determine serum protein adsorption and macrophage uptake. J. Am. Chem Soc. 2012, 134, 2139-2147. [CrossRef]

18. Hsu, H.J.; Bugno, J.; Lee, S.R.; Hong, S. Dendrimer-based nanocarriers: A versatile platform for drug delivery. Wiley Interdiscip Rev. Nanomed. Nanobiotechnol. 2017, 9, 1-21. [CrossRef]

19. Palmerston Mendes, L.; Pan, J.; Torchilin, V.P. Dendrimers as Nanocarriers for Nucleic Acid and Drug Delivery in Cancer Therapy. Molecules 2017, 22, 1401. [CrossRef]

20. Crucho, C.I.C.; Barros, M.T. Polymeric nanoparticles: A study on the preparation variables and characterization methods. Mater. Sci Eng. C Mater. Biol. Appl. 2017, 80,771-784. [CrossRef]

21. Letchford, K.; Liggins, R.; Wasan, K.M.; Burt, H. In vitro human plasma distribution of nanoparticulate paclitaxel is dependent on the physicochemical properties of poly(ethylene glycol)-block-poly(caprolactone) nanoparticles. Eur. J. Pharm. Biopharm. 2009, 71, 196-206. [CrossRef]

22. Ahmad, Z.; Shah, A.; Siddiq, M.; Kraatz, H.-B. Polymeric micelles as drug delivery vehicles. RSC Adv. 2014, 4, 17028-17038. [CrossRef]

23. Markovsky, E.; Baabur-Cohen, H.; Satchi-Fainaro, R. Anticancer polymeric nanomedicine bearing synergistic drug combination is superior to a mixture of individually-conjugated drugs. J. Control. Release 2014, 187, 145-157. [CrossRef] [PubMed]

24. Yang, R.; Mondal, G.; Wen, D.; Mahato, R.I. Combination therapy of paclitaxel and cyclopamine polymer-drug conjugates to treat advanced prostate cancer. Nanomed. -Uk 2017, 13, 391-401. [CrossRef] [PubMed]

25. Pang, X.; Jiang, Y.; Xiao, Q.; Leung, A.W.; Hua, H.; Xu, C. pH-responsive polymer-drug conjugates: Design and progress. J. Control. Release 2016, 222, 116-129. [CrossRef] 
26. Lv, S.; Tang, Z.; Zhang, D.; Song, W.; Li, M.; Lin, J.; Liu, H.; Chen, X. Well-defined polymer-drug conjugate engineered with redox and $\mathrm{pH}$-sensitive release mechanism for efficient delivery of paclitaxel. J. Control. Release 2014, 194, 220-227. [CrossRef]

27. Chen, Z.; Zhang, P.; Cheetham, A.G.; Moon, J.H.; Moxley, J.W., Jr.; Lin, Y.A.; Cui, H. Controlled release of free doxorubicin from peptide-drug conjugates by drug loading. J. Control. Release 2014, 191, 123-130. [CrossRef]

28. Tu, Y.; Zhu, L. Enhancing cancer targeting and anticancer activity by a stimulus-sensitive multifunctional polymer-drug conjugate. J. Control. Release 2015, 212, 94-102. [CrossRef]

29. Hill, B.D.; Zak, A.; Khera, E.; Wen, F. Engineering Virus-like Particles for Antigen and Drug Delivery. Curr. Protein Pept. Sci. 2018, 19, 112-127. [CrossRef]

30. Lopez-Sagaseta, J.; Malito, E.; Rappuoli, R.; Bottomley, M.J. Self-assembling protein nanoparticles in the design of vaccines. Comput. Struct. Biotechnol. J. 2016, 14, 58-68. [CrossRef]

31. Neek, M.; Kim, T.I.; Wang, S.-W. Protein-based nanoparticles in cancer vaccine development. Nanomed. Nanotechnol. Biol. Med. 2019, 15, 164-174. [CrossRef]

32. Tarhini, M.; Greige-Gerges, H.; Elaissari, A. Protein-based nanoparticles: From preparation to encapsulation of active molecules. Int. J. Pharm. 2017, 522, 172-197. [CrossRef] [PubMed]

33. Lohcharoenkal, W.; Wang, L.; Chen, Y.C.; Rojanasakul, Y. Protein nanoparticles as drug delivery carriers for cancer therapy. Biomed. Res. Int. 2014, 2014, 180549. [CrossRef]

34. Herrera Estrada, L.P.; Champion, J.A. Protein nanoparticles for therapeutic protein delivery. Biomater. Sci. 2015, 3, 787-799. [CrossRef]

35. Alemán, J.V.; Chadwick, A.V.; He, J.; Hess, M.; Horie, K.; Jones, R.G.; Kratochvíl, P.; Meisel, I.; Mita, I.; Moad, G.; et al. Definitions of terms relating to the structure and processing of sols, gels, networks, and inorganic-organic hybrid materials (IUPAC Recommendations 2007). Pure Appl. Chem. 2007, 79, 1801-1829. [CrossRef]

36. Tahara, Y.; Akiyoshi, K. Current advances in self-assembled nanogel delivery systems for immunotherapy. Adv. Drug Deliv. Rev. 2015, 95, 65-76. [CrossRef] [PubMed]

37. Sharma, A.; Garg, T.; Aman, A.; Panchal, K.; Sharma, R.; Kumar, S.; Markandeywar, T. Nanogel—An advanced drug delivery tool: Current and future. Artif. Cells Nanomed. Biotechnol. 2016, 44, 165-177. [CrossRef] [PubMed]

38. Akiyoshi, K.; Deguchi, S.; Moriguchi, N.; Yamaguchi, S.; Sunamoto, J. Self-aggregates of hydrophobized polysaccharides in water. Formation and characteristics of nanoparticles. Macromolecules 1993, 26, 3062-3068. [CrossRef]

39. Neamtu, I.; Rusu, A.G.; Diaconu, A.; Nita, L.E.; Chiriac, A.P. Basic concepts and recent advances in nanogels as carriers for medical applications. Drug Deliv. 2017, 24, 539-557. [CrossRef]

40. Iijima, S. Helical microtubules of graphitic carbon. Nature 1991, 354, 56-58. [CrossRef]

41. Reilly, R.M. Carbon nanotubes: Potential benefits and risks of nanotechnology in nuclear medicine. J. Nucl. Med. 2007, 48, 1039-1042. [CrossRef]

42. Mroz, P.; Pawlak, A.; Satti, M.; Lee, H.; Wharton, T.; Gali, H.; Sarna, T.; Hamblin, M.R. Functionalized fullerenes mediate photodynamic killing of cancer cells: Type I versus Type II photochemical mechanism. Free Radic Biol. Med. 2007, 43, 711-719. [CrossRef] [PubMed]

43. Tegos, G.P.; Demidova, T.N.; Arcila-lopez, D.; Lee, H.; Wharton, T.; Gali, H.; Hamblin, M.R. Cationic Fullerenes Are Effective and Selective Antimicrobial Photosensitizers. NIH Public Access. 2011, 12, 1127-1135. [CrossRef] [PubMed]

44. Bosi, S.; Da Ros, T.; Castellano, S.; Banfi, E.; Prato, M. Antimycobacterial activity of ionic fullerene derivatives. Bioorg. Med. Chem. Lett. 2000, 10, 1043-1045. [CrossRef]

45. Ji, H.; Yang, Z.; Jiang, W.; Geng, C.; Gong, M.; Xiao, H.; Wang, Z.; Cheng, L. Antiviral activity of nano carbon fullerene lipidosome against influenza virus in vitro. J. Huazhong Univ. Sci. Technol. Med. Sci. 2008, 28, 243-246. [CrossRef]

46. Cai, X.; Jia, H.; Liu, Z.; Hou, B.; Luo, C.; Feng, Z.; Li, W.; Liu, J. Polyhydroxylated fullerene derivative $\mathrm{C}(60)(\mathrm{OH})(24)$ prevents mitochondrial dysfunction and oxidative damage in an $\mathrm{MPP}(+)$-induced cellular model of Parkinson's disease. J. Neurosci. Res. 2008, 86, 3622-3634. [CrossRef]

47. Markovic, Z.; Trajkovic, V. Biomedical potential of the reactive oxygen species generation and quenching by fullerenes (C60). Biomaterials 2008, 29, 3561-3573. [CrossRef] 
48. Torres Sangiao, E.; Holban, A.M.; Gestal, M.C. Applications of Nanodiamonds in the Detection and Therapy of Infectious Diseases. Mater. (Basel) 2019, 12, 1639. [CrossRef]

49. Man, H.B.; Ho, D. Nanodiamonds as platforms for biology and medicine. J. Lab. Autom 2013, 18, 12-18. [CrossRef]

50. Ho, D.; Wang, C.H.; Chow, E.K. Nanodiamonds: The intersection of nanotechnology, drug development, and personalized medicine. Sci. Adv. 2015, 1, e1500439. [CrossRef]

51. van der Laan, K.; Hasani, M.; Zheng, T.; Schirhagl, R. Nanodiamonds for In Vivo Applications. Small 2018, 14, 1703838. [CrossRef]

52. Tinwala, H.; Wairkar, S. Production, surface modification and biomedical applications of nanodiamonds: A sparkling tool for theranostics. Mater. Sci. Eng. C 2019, 97, 913-931. [CrossRef]

53. Chakrabarti, K.; Chakrabarti, R.; Chattopadhyay, K.K.; Chaudhuri, S.; Pal, A.K. Nano-diamond films produced from CVD of camphor. Diam. Relat. Mater. 1998, 7, 845-852. [CrossRef]

54. Cuenca, A.G.; Jiang, H.; Hochwald, S.N.; Delano, M.; Cance, W.G.; Grobmyer, S.R. Emerging implications of nanotechnology on cancer diagnostics and therapeutics. Cancer 2006, 107, 459-466. [CrossRef] [PubMed]

55. Fan, C.; Gao, W.; Chen, Z.; Fan, H.; Li, M.; Deng, F.; Chen, Z. Tumor selectivity of stealth multi-functionalized superparamagnetic iron oxide nanoparticles. Int J. Pharm. 2011, 404, 180-190. [CrossRef] [PubMed]

56. Andocs, G.; Renner, H.; Balogh, L.; Fonyad, L.; Jakab, C.; Szasz, A. Strong synergy of heat and modulated electromagnetic field in tumor cell killing. Strahlenther Onkol 2009, 185, 120-126. [CrossRef]

57. Pandey, B.; Shetake, N.; Balla, M.S.; Kumar, A. Magnetic hyperthermia therapy: An emerging modality of cancer treatment in combination with radiotherapy. J. Radiat. Cancer Res. 2016, 7, 13. [CrossRef]

58. Mura, S.; Nicolas, J.; Couvreur, P. Stimuli-responsive nanocarriers for drug delivery. Nat. Mater. 2013, 12, 991-1003. [CrossRef]

59. Tian, L.; Lu, L.; Qiao, Y.; Ravi, S.; Salatan, F.; Melancon, M.P. Stimuli-Responsive Gold Nanoparticles for Cancer Diagnosis and Therapy. J. Funct. Biomater. 2016, 7, 19. [CrossRef]

60. Singh, P.; Pandit, S.; Mokkapati, V.; Garg, A.; Ravikumar, V.; Mijakovic, I. Gold Nanoparticles in Diagnostics and Therapeutics for Human Cancer. Int. J. Mol. Sci. 2018, 19. [CrossRef]

61. Masse, F.; Ouellette, M.; Lamoureux, G.; Boisselier, E. Gold nanoparticles in ophthalmology. Med. Res. Rev. 2019, 39, 302-327. [CrossRef]

62. Kim, H.; Beack, S.; Han, S.; Shin, M.; Lee, T.; Park, Y.; Kim, K.S.; Yetisen, A.K.; Yun, S.H.; Kwon, W.; et al. Multifunctional Photonic Nanomaterials for Diagnostic, Therapeutic, and Theranostic Applications. Adv. Mater. 2018, 30,1-33. [CrossRef] [PubMed]

63. Iga, A.M.; Robertson, J.H.; Winslet, M.C.; Seifalian, A.M. Clinical potential of quantum dots. J. Biomed. Biotechnol. 2007, 2007, 76087. [CrossRef] [PubMed]

64. Matea, C.T.; Mocan, T.; Tabaran, F.; Pop, T.; Mosteanu, O.; Puia, C.; Iancu, C.; Mocan, L. Quantum dots in imaging, drug delivery and sensor applications. Int. J. Nanomed. 2017, 12, 5421-5431. [CrossRef] [PubMed]

65. Bailey, R.E.; Smith, A.M.; Nie, S. Quantum dots in biology and medicine. Phys. E Low-Dimens. Syst. Nanostructures 2004, 25, 1-12. [CrossRef]

66. Chen, F.; Hableel, G.; Zhao, E.R.; Jokerst, J.V. Multifunctional nanomedicine with silica: Role of silica in nanoparticles for theranostic, imaging, and drug monitoring. J. Colloid Interface Sci. 2018, 521, 261-279. [CrossRef]

67. Bharali, D.J.; Klejbor, I.; Stachowiak, E.K.; Dutta, P.; Roy, I.; Kaur, N.; Bergey, E.J.; Prasad, P.N.; Stachowiak, M.K. Organically modified silica nanoparticles: A nonviral vector for in vivo gene delivery and expression in the brain. Proc. Natl. Acad. Sci. USA 2005, 102, 11539-11544. [CrossRef]

68. Bagheri, E.; Ansari, L.; Abnous, K.; Taghdisi, S.M.; Charbgoo, F.; Ramezani, M.; Alibolandi, M. Silica based hybrid materials for drug delivery and bioimaging. J. Control. Release 2018, 277, 57-76. [CrossRef]

69. Leucuta, S.E. Nanotechnology for delivery of drugs and biomedical applications. Curr. Clin. Pharm. 2010, 5, 257-280. [CrossRef]

70. Buse, J.; El-Aneed, A. Properties, engineering and applications of lipid-based nanoparticle drug-delivery systems: Current research and advances. Nanomedicine (Lond) 2010, 5, 1237-1260. [CrossRef]

71. Daraee, H.; Etemadi, A.; Kouhi, M.; Alimirzalu, S.; Akbarzadeh, A. Application of liposomes in medicine and drug delivery. Artif. Cells Nanomed. Biotechnol. 2016, 44, 381-391. [CrossRef]

72. Oberholzer, T.; Luisi, P.L. The use of liposomes for constructing cell models. J. Biol. Phys. 2002, 28, 733-744. [CrossRef] [PubMed] 
73. Patil, Y.P.; Jadhav, S. Novel methods for liposome preparation. Chem. Phys. Lipids 2014, 177, 8-18. [CrossRef] [PubMed]

74. Sercombe, L.; Veerati, T.; Moheimani, F.; Wu, S.Y.; Sood, A.K.; Hua, S. Advances and Challenges of Liposome Assisted Drug Delivery. Front. Pharm. 2015, 6, 286. [CrossRef] [PubMed]

75. Gabizon, A.; Catane, R.; Uziely, B.; Kaufman, B.; Safra, T.; Cohen, R.; Martin, F.; Huang, A.; Barenholz, Y. Prolonged circulation time and enhanced accumulation in malignant exudates of doxorubicin encapsulated in polyethylene-glycol coated liposomes. Cancer Res. 1994, 54, 987-992.

76. He, C.; Zheng, S.; Luo, Y.; Wang, B. Exosome Theranostics: Biology and Translational Medicine. Theranostics 2018, 8, 237-255. [CrossRef]

77. Shimasaki, T.; Yamamoto, S.; Arisawa, T. Exosome Research and Co-culture Study. Biol. Pharm. Bull. 2018, 41, 1311-1321. [CrossRef]

78. Yamashita, T.; Takahashi, Y.; Takakura, Y. Possibility of Exosome-Based Therapeutics and Challenges in Production of Exosomes Eligible for Therapeutic Application. Biol. Pharm Bull. 2018, 41, 835-842. [CrossRef]

79. Urbanelli, L.; Buratta, S.; Sagini, K.; Ferrara, G.; Lanni, M.; Emiliani, C. Exosome-based strategies for Diagnosis and Therapy. Recent Pat. Cns Drug Discov. 2015, 10, 10-27. [CrossRef]

80. Batrakova, E.V.; Kim, M.S. Using exosomes, naturally-equipped nanocarriers, for drug delivery. J. Control. Release 2015, 219, 396-405. [CrossRef]

81. Familtseva, A.; Jeremic, N.; Tyagi, S.C. Exosomes: Cell-created drug delivery systems. Mol. Cell. Biochem. 2019, 459, 1-6. [CrossRef]

82. Wu, P.; Zhang, B.; Shi, H.; Qian, H.; Xu, W. MSC-exosome: A novel cell-free therapy for cutaneous regeneration. Cytotherapy 2018, 20, 291-301. [CrossRef] [PubMed]

83. de Jesus, M.B.; Zuhorn, I.S. Solid lipid nanoparticles as nucleic acid delivery system: Properties and molecular mechanisms. J. Control. Release 2015, 201, 1-13. [CrossRef] [PubMed]

84. Doktorovova, S.; Souto, E.B.; Silva, A.M. Nanotoxicology applied to solid lipid nanoparticles and nanostructured lipid carriers - a systematic review of in vitro data. Eur. J. Pharm. Biopharm. 2014, 87, 1-18. [CrossRef]

85. Ezzati Nazhad Dolatabadi, J.; Valizadeh, H.; Hamishehkar, H. Solid Lipid Nanoparticles as Efficient Drug and Gene Delivery Systems: Recent Breakthroughs. Adv. Pharm. Bull. 2015, 5, 151-159. [CrossRef] [PubMed]

86. Rostami, E.; Kashanian, S.; Azandaryani, A.H.; Faramarzi, H.; Dolatabadi, J.E.; Omidfar, K. Drug targeting using solid lipid nanoparticles. Chem. Phys. Lipids 2014, 181, 56-61. [CrossRef] [PubMed]

87. Shen, H.; Shi, S.; Zhang, Z.; Gong, T.; Sun, X. Coating Solid Lipid Nanoparticles with Hyaluronic Acid Enhances Antitumor Activity against Melanoma Stem-like Cells. Theranostics 2015, 5, 755-771. [CrossRef]

88. Weber, S.; Zimmer, A.; Pardeike, J. Solid Lipid Nanoparticles (SLN) and Nanostructured Lipid Carriers (NLC) for pulmonary application: A review of the state of the art. Eur J. Pharm. Biopharm. 2014, 86, 7-22. [CrossRef]

89. Luo, Y.; Teng, Z.; Li, Y.; Wang, Q. Solid lipid nanoparticles for oral drug delivery: Chitosan coating improves stability, controlled delivery, mucoadhesion and cellular uptake. Carbohydr. Polym. 2015, 122, 221-229. [CrossRef]

90. Junyaprasert, V.B.; Morakul, B. Nanocrystals for enhancement of oral bioavailability of poorly water-soluble drugs. Asian J. Pharm. Sci. 2015, 10, 13-23. [CrossRef]

91. Davis, M.E.; Chen, Z.G.; Shin, D.M. Nanoparticle therapeutics: An emerging treatment modality for cancer. Nat. Rev. Drug Discov. 2008, 7,771-782. [CrossRef]

92. Silverman, J.A.; Deitcher, S.R. Marqibo(R) (vincristine sulfate liposome injection) improves the pharmacokinetics and pharmacodynamics of vincristine. Cancer Chemother Pharm. 2013, 71, 555-564. [CrossRef] [PubMed]

93. Venkatakrishnan, K.; Liu, Y.; Noe, D.; Mertz, J.; Bargfrede, M.; Marbury, T.; Farbakhsh, K.; Oliva, C.; Milton, A. Pharmacokinetics and pharmacodynamics of liposomal mifamurtide in adult volunteers with mild or moderate renal impairment. Br. J. Clin. Pharm. 2014, 77, 986-997. [CrossRef] [PubMed]

94. Zhang, H. Onivyde for the therapy of multiple solid tumors. Onco Targets 2016, 9, 3001-3007. [CrossRef] [PubMed]

95. Anselmo, A.C.; Mitragotri, S. Nanoparticles in the clinic: An update. Bioeng. Transl. Med. 2019, 4, e10143. [CrossRef] [PubMed] 
96. Akinc, A.; Maier, M.A.; Manoharan, M.; Fitzgerald, K.; Jayaraman, M.; Barros, S.; Ansell, S.; Du, X.; Hope, M.J.; Madden, T.D.; et al. The Onpattro story and the clinical translation of nanomedicines containing nucleic acid-based drugs. Nat. Nanotechnol. 2019, 14, 1084-1087. [CrossRef]

97. Komlosh, A.; Weinstein, V.; Loupe, P.; Hasson, T.; Timan, B.; Konya, A.; Alexander, J.; Melamed-Gal, S.; Nock, S. Physicochemical and Biological Examination of Two Glatiramer Acetate Products. Biomedicines 2019, 7, 49. [CrossRef]

98. Kim, M.T.; Chen, Y.; Marhoul, J.; Jacobson, F. Statistical modeling of the drug load distribution on trastuzumab emtansine (Kadcyla), a lysine-linked antibody drug conjugate. Bioconjug Chem. 2014, 25, 1223-1232. [CrossRef]

99. Miele, E.; Spinelli, G.P.; Miele, E.; Tomao, F.; Tomao, S. Albumin-bound formulation of paclitaxel (Abraxane ABI-007) in the treatment of breast cancer. Int. J. Nanomed. 2009, 4, 99-105. [CrossRef]

100. Patra, J.K.; Das, G.; Fraceto, L.F.; Campos, E.V.R.; Rodriguez-Torres, M.D.P.; Acosta-Torres, L.S.; Diaz-Torres, L.A.; Grillo, R.; Swamy, M.K.; Sharma, S.; et al. Nano based drug delivery systems: Recent developments and future prospects. J. Nanobiotechnol. 2018, 16, 71. [CrossRef]

101. Chelle, P.; Yeung, C.H.T.; Croteau, S.E.; Lissick, J.; Balasa, V.; Ashburner, C.; Park, Y.S.; Bonanad, S.; Megías-Vericat, J.E.; Nagao, A.; et al. Development and Validation of a Population-Pharmacokinetic Model for Rurioctacog Alfa Pegol (Adynovate ${ }^{\circledR}$ ): A Report on Behalf of the WAPPS-Hemo Investigators Ad Hoc Subgroup. Clin. Pharmacokinet. 2020, 59, 245-256. [CrossRef]

102. Farjadian, F.; Ghasemi, A.; Gohari, O.; Roointan, A.; Karimi, M.; Hamblin, M.R. Nanopharmaceuticals and nanomedicines currently on the market: Challenges and opportunities. Nanomedicine (Lond) 2019, 14, 93-126. [CrossRef] [PubMed]

103. Bullivant, J.P.; Zhao, S.; Willenberg, B.J.; Kozissnik, B.; Batich, C.D.; Dobson, J. Materials characterization of Feraheme/ferumoxytol and preliminary evaluation of its potential for magnetic fluid hyperthermia. Int. J. Mol. Sci. 2013, 14, 17501-17510. [CrossRef] [PubMed]

104. Lyseng-Williamson, K.A.; Keating, G.M. Ferric Carboxymaltose. Drugs 2009, 69, 739-756. [CrossRef] [PubMed]

105. Weissig, V.; Pettinger, T.K.; Murdock, N. Nanopharmaceuticals (part 1): Products on the market. Int. J. Nanomed. 2014, 9, 4357-4373. [CrossRef]

106. Choi, Y.H.; Han, H.K. Nanomedicines: Current status and future perspectives in aspect of drug delivery and pharmacokinetics. J. Pharm. Investig. 2018, 48, 43-60. [CrossRef]

107. Kaduk, J.A.; Dmitrienko, A.O.; Gindhart, A.M.; Blanton, T.N. Crystal structure of paliperidone palmitate (INVEGA SUSTENNA ${ }^{\circledR}$ ), C39H57FN4O4. Powder Diffr. 2017, 32, 222-227. [CrossRef]

108. Chidambaram, M.; Manavalan, R.; Kathiresan, K. Nanotherapeutics to overcome conventional cancer chemotherapy limitations. J. Pharm. Pharm. Sci. 2011, 14, 67-77. [CrossRef]

109. Stavrovskaya, A.A. Cellular mechanisms of multidrug resistance of tumor cells. Biochemistry (Mosc) 2000, 65, 95-106.

110. Mishra, B.; Patel, B.B.; Tiwari, S. Colloidal nanocarriers: A review on formulation technology, types and applications toward targeted drug delivery. Nanomed. -UK 2010, 6, 9-24. [CrossRef]

111. Danhier, F.; Feron, O.; Preat, V. To exploit the tumor microenvironment: Passive and active tumor targeting of nanocarriers for anti-cancer drug delivery. J. Control. Release 2010, 148, 135-146. [CrossRef]

112. Maeda, H.; Bharate, G.Y.; Daruwalla, J. Polymeric drugs for efficient tumor-targeted drug delivery based on EPR-effect. Eur. J. Pharm. Biopharm. 2009, 71, 409-419. [CrossRef] [PubMed]

113. Tong, R.; Hemmati, H.D.; Langer, R.; Kohane, D.S. Photoswitchable nanoparticles for triggered tissue penetration and drug delivery. J. Am. Chem Soc. 2012, 134, 8848-8855. [CrossRef] [PubMed]

114. Din, F.U.; Aman, W.; Ullah, I.; Qureshi, O.S.; Mustapha, O.; Shafique, S.; Zeb, A. Effective use of nanocarriers as drug delivery systems for the treatment of selected tumors. Int. J. Nanomed. 2017, 12, 7291-7309. [CrossRef] [PubMed]

115. Barenholz, Y. Doxil(R)—The first FDA-approved nano-drug: Lessons learned. J. Control. Release 2012, 160, 117-134. [CrossRef] [PubMed]

116. O’Brien, S.; Schiller, G.; Lister, J.; Damon, L.; Goldberg, S.; Aulitzky, W.; Ben-Yehuda, D.; Stock, W.; Coutre, S.; Douer, D.; et al. High-dose vincristine sulfate liposome injection for advanced, relapsed, and refractory adult Philadelphia chromosome-negative acute lymphoblastic leukemia. J. Clin. Oncol. 2013, 31, 676-683. [CrossRef] [PubMed] 
117. Misra, R.; Acharya, S.; Sahoo, S.K. Cancer nanotechnology: Application of nanotechnology in cancer therapy. Drug Discov. Today 2010, 15, 842-850. [CrossRef]

118. Cohen, S.M.; Rockefeller, N.; Mukerji, R.; Durham, D.; Forrest, M.L.; Cai, S.; Cohen, M.S.; Shnayder, Y. Efficacy and toxicity of peritumoral delivery of nanoconjugated cisplatin in an in vivo murine model of head and neck squamous cell carcinoma. JAMA Otolaryngol. Head Neck Surg 2013, 139, 382-387. [CrossRef]

119. Stathopoulos, G.P.; Boulikas, T. Lipoplatin formulation review article. J. Drug Deliv. 2012, 2012, 581363. [CrossRef]

120. Boulikas, T. Low toxicity and anticancer activity of a novel liposomal cisplatin (Lipoplatin) in mouse xenografts. Oncol. Rep. 2004, 12, 3-12. [CrossRef]

121. Boulikas, T. Clinical overview on Lipoplatin: A successful liposomal formulation of cisplatin. Expert Opin. Investig. Drugs 2009, 18, 1197-1218. [CrossRef]

122. Farhat, F.; Kattan, J.; Ibrahim, K.; Bitar, N.; Haddad, N.; Tamraz, S.; Hatoum, H.; Shamseddine, A. 457 Preliminary results of a phase II study of lipoplatin (liposomal cisplatin)-vinorelbine combination as first line treatment in HER2/neu negative metastatic breast cancer (MBC). Eur. J. Cancer Suppl. 2010, 8, 192. [CrossRef]

123. Panowski, S.; Bhakta, S.; Raab, H.; Polakis, P.; Junutula, J.R. Site-specific antibody drug conjugates for cancer therapy. MAbs 2014, 6, 34-45. [CrossRef] [PubMed]

124. Xu, Z.; Guo, D.; Jiang, Z.; Tong, R.; Jiang, P.; Bai, L.; Chen, L.; Zhu, Y.; Guo, C.; Shi, J.; et al. Novel HER2-Targeting Antibody-Drug Conjugates of Trastuzumab Beyond T-DM1 in Breast Cancer: Trastuzumab Deruxtecan(DS-8201a) and (Vic-)Trastuzumab Duocarmazine (SYD985). Eur. J. Med. Chem. 2019, 183, 111682. [CrossRef] [PubMed]

125. Chen, L.; Wang, L.; Shion, H.; Yu, C.; Yu, Y.Q.; Zhu, L.; Li, M.; Chen, W.; Gao, K. In-depth structural characterization of Kadcyla(R) (ado-trastuzumab emtansine) and its biosimilar candidate. MAbs 2016, 8, 1210-1223. [CrossRef] [PubMed]

126. Gradishar, W.J. Albumin-bound paclitaxel: A next-generation taxane. Expert Opin. Pharm. 2006, 7, 1041-1053. [CrossRef] [PubMed]

127. Wang, X.; Wang, C.; Zhang, Q.; Cheng, Y. Near infrared light-responsive and injectable supramolecular hydrogels for on-demand drug delivery. Chem. Commun. (Camb) 2016, 52, 978-981. [CrossRef]

128. A Clinical Study to Measure the Effect of OP-101 after Being Administered Subcutaneous in Healthy Volunteers. Available online: https://ClinicalTrials.gov/show/NCT04321980:2018 (accessed on 13 April 2020).

129. Dai, L.; Yu, Y.; Luo, Z.; Li, M.; Chen, W.; Shen, X.; Chen, F.; Sun, Q.; Zhang, Q.; Gu, H.; et al. Photosensitizer enhanced disassembly of amphiphilic micelle for ROS-response targeted tumor therapy in vivo. Biomaterials 2016, 104, 1-17. [CrossRef]

130. Fujiwara, Y.; Mukai, H.; Saeki, T.; Ro, J.; Lin, Y.-C.; Nagai, S.E.; Lee, K.S.; Watanabe, J.; Ohtani, S.; Kim, S.B.; et al. A multi-national, randomised, open-label, parallel, phase III non-inferiority study comparing NK105 and paclitaxel in metastatic or recurrent breast cancer patients. Br. J. Cancer 2019, 120, 475-480. [CrossRef]

131. Bhirde, A.A.; Patel, S.; Sousa, A.A.; Patel, V.; Molinolo, A.A.; Ji, Y.; Leapman, R.D.; Gutkind, J.S.; Rusling, J.F. Distribution and clearance of PEG-single-walled carbon nanotube cancer drug delivery vehicles in mice. Nanomed. (Lond. Engl.) 2010, 5, 1535-1546. [CrossRef]

132. Feng, Q.; Zhang, Y.; Zhang, W.; Hao, Y.; Wang, Y.; Zhang, H.; Hou, L.; Zhang, Z. Programmed near-infrared light-responsive drug delivery system for combined magnetic tumor-targeting magnetic resonance imaging and chemo-phototherapy. Acta Biomater 2017, 49, 402-413. [CrossRef]

133. Feng, Q.; Zhang, Y.; Zhang, W.; Shan, X.; Yuan, Y.; Zhang, H.; Hou, L.; Zhang, Z. Tumor-targeted and multi-stimuli responsive drug delivery system for near-infrared light induced chemo-phototherapy and photoacoustic tomography. Acta Biomater 2016, 38, 129-142. [CrossRef] [PubMed]

134. Liu, T.; Wang, C.; Gu, X.; Gong, H.; Cheng, L.; Shi, X.; Feng, L.; Sun, B.; Liu, Z. Drug delivery with PEGylated MoS2 nano-sheets for combined photothermal and chemotherapy of cancer. Adv. Mater. 2014, 26, 3433-3440. [CrossRef] [PubMed]

135. Chen, L.; Wu, L.; Liu, F.; Qi, X.; Ge, Y.; Shen, S. Azo-functionalized Fe3O4 nanoparticles: A near-infrared light triggered drug delivery system for combined therapy of cancer with low toxicity. J. Mater. Chem. B 2016, 4, 3660-3669. [CrossRef]

136. Chen, J.; Li, X.; Zhao, X.; Wu, Q.; Zhu, H.; Mao, Z.; Gao, C. Doxorubicin-conjugated pH-responsive gold nanorods for combined photothermal therapy and chemotherapy of cancer. Bioact Mater. 2018, 3, 347-354. [CrossRef] [PubMed] 
137. Kharlamov, A.N.; Feinstein, J.A.; Cramer, J.A.; Boothroyd, J.A.; Shishkina, E.V.; Shur, V. Plasmonic photothermal therapy of atherosclerosis with nanoparticles: Long-term outcomes and safety in NANOM-FIM trial. Future Cardiol. 2017, 13, 345-363. [CrossRef]

138. Choi, J.; Park, Y.; Choi, E.B.; Kim, H.O.; Kim, D.J.; Hong, Y.; Ryu, S.H.; Lee, J.H.; Suh, J.S.; Yang, J.; et al. Aptamer-conjugated gold nanorod for photothermal ablation of epidermal growth factor receptor-overexpressed epithelial cancer. J. Biomed. Opt. 2014, 19, 051203. [CrossRef]

139. Liu, Y.; Ding, X.; Li, J.; Luo, Z.; Hu, Y.; Liu, J.; Dai, L.; Zhou, J.; Hou, C.; Cai, K. Enzyme responsive drug delivery system based on mesoporous silica nanoparticles for tumor therapy in vivo. Nanotechnology 2015, 26, 145102. [CrossRef]

140. Zhou, J.; Li, M.; Lim, W.Q.; Luo, Z.; Phua, S.Z.F.; Huo, R.; Li, L.; Li, K.; Dai, L.; Liu, J.; et al. A Transferrin-Conjugated Hollow Nanoplatform for Redox-Controlled and Targeted Chemotherapy of Tumor with Reduced Inflammatory Reactions. Theranostics 2018, 8, 518-532. [CrossRef] [PubMed]

141. Zhang, Q.; Wang, X.; Li, P.-Z.; Nguyen, K.T.; Wang, X.-J.; Luo, Z.; Zhang, H.; Tan, N.S.; Zhao, Y. Biocompatible, Uniform, and Redispersible Mesoporous Silica Nanoparticles for Cancer-Targeted Drug Delivery In Vivo. Adv. Funct. Mater. 2014, 24, 2450-2461. [CrossRef]

142. Pei, Y.; Li, M.; Hou, Y.; Hu, Y.; Chu, G.; Dai, L.; Li, K.; Xing, Y.; Tao, B.; Yu, Y.; et al. An autonomous tumor-targeted nanoprodrug for reactive oxygen species-activatable dual-cytochrome c/doxorubicin antitumor therapy. Nanoscale 2018, 10, 11418-11429. [CrossRef]

143. Canullo, L.; Dellavia, C.; Heinemann, F. Maxillary sinus floor augmentation using a nano-crystalline hydroxyapatite silica gel: Case series and 3-month preliminary histological results. Ann. Anat. -Anat. Anz. 2012, 194, 174-178. [CrossRef] [PubMed]

144. Madamsetty, V.S.; Sharma, A.; Toma, M.; Samaniego, S.; Gallud, A.; Wang, E.; Pal, K.; Mukhopadhyay, D.; Fadeel, B. Tumor selective uptake of drug-nanodiamond complexes improves therapeutic outcome in pancreatic cancer. Nanomed. Nanotechnol. Biol. Med. 2019, 18, 112-121. [CrossRef] [PubMed]

145. Madamsetty, V.S.; Pal, K.; Keshavan, S.; Caulfield, T.R.; Dutta, S.K.; Wang, E.; Fadeel, B.; Mukhopadhyay, D. Development of multi-drug loaded PEGylated nanodiamonds to inhibit tumor growth and metastasis in genetically engineered mouse models of pancreatic cancer. Nanoscale 2019, 11, 22006-22018. [CrossRef] [PubMed]

146. Hillaireau, H.; Couvreur, P. Nanocarriers' entry into the cell: Relevance to drug delivery. Cell Mol. Life Sci. 2009, 66, 2873-2896. [CrossRef] [PubMed]

147. Sendi, P.; Proctor, R.A. Staphylococcus aureus as an intracellular pathogen: The role of small colony variants. Trends Microbiol. 2009, 17, 54-58. [CrossRef]

148. Zazo, H.; Colino, C.I.; Lanao, J.M. Current applications of nanoparticles in infectious diseases. J. Control. Release 2016, 224, 86-102. [CrossRef]

149. Corporation, A. ARD-3150 Pulmaquin ${ }^{\circledR}$ and ARD-3100 Lipoquin ${ }^{\circledR}$. Available online: www.aradigm.com/ products_3100.html (accessed on 22 March 2020).

150. Walsh, T.J.; Finberg, R.W.; Arndt, C.; Hiemenz, J.; Schwartz, C.; Bodensteiner, D.; Pappas, P.; Seibel, N.; Greenberg, R.N.; Dummer, S.; et al. Liposomal amphotericin B for empirical therapy in patients with persistent fever and neutropenia. National Institute of Allergy and Infectious Diseases Mycoses Study Group. N. Engl. J. Med. 1999, 340, 764-771. [CrossRef]

151. Cornely, O.A.; Maertens, J.; Bresnik, M.; Ebrahimi, R.; Ullmann, A.J.; Bouza, E.; Heussel, C.P.; Lortholary, O.; Rieger, C.; Boehme, A.; et al. Liposomal amphotericin B as initial therapy for invasive mold infection: A randomized trial comparing a high-loading dose regimen with standard dosing (AmBiLoad trial). Clin. Infect. Dis. 2007, 44, 1289-1297. [CrossRef]

152. Ghaffar, K.A.; Giddam, A.K.; Zaman, M.; Skwarczynski, M.; Toth, I. Liposomes as nanovaccine delivery systems. Curr. Top. Med. Chem. 2014, 14, 1194-1208. [CrossRef]

153. Wang, L.; Hu, C.; Shao, L. The antimicrobial activity of nanoparticles: Present situation and prospects for the future. Int. J. Nanomed. 2017, 12, 1227-1249. [CrossRef]

154. Wu, K.; Yang, Y.; Zhang, Y.; Deng, J.; Lin, C. Antimicrobial activity and cytocompatibility of silver nanoparticles coated catheters via a biomimetic surface functionalization strategy. Int. J. Nanomed. 2015, 10, 7241-7252. [CrossRef]

155. Bozzuto, G.; Molinari, A. Liposomes as nanomedical devices. Int. J. Nanomed. 2015, 10, 975-999. [CrossRef] [PubMed] 
156. Beal, S.G.; Ciurca, J.; Smith, G.; John, J.; Lee, F.; Doern, C.D.; Gander, R.M. Evaluation of the nanosphere verigene gram-positive blood culture assay with the VersaTREK blood culture system and assessment of possible impact on selected patients. J. Clin. Microbiol. 2013, 51, 3988-3992. [CrossRef] [PubMed]

157. Longhi, C.; Santos, J.P.; Morey, A.T.; Marcato, P.D.; Duran, N.; Pinge-Filho, P.; Nakazato, G.; Yamada-Ogatta, S.F.; Yamauchi, L.M. Combination of fluconazole with silver nanoparticles produced by Fusarium oxysporum improves antifungal effect against planktonic cells and biofilm of drug-resistant Candida albicans. Med. Mycol. 2016, 54, 428-432. [CrossRef] [PubMed]

158. Brown, A.N.; Smith, K.; Samuels, T.A.; Lu, J.; Obare, S.O.; Scott, M.E. Nanoparticles functionalized with ampicillin destroy multiple-antibiotic-resistant isolates of Pseudomonas aeruginosa and Enterobacter aerogenes and methicillin-resistant Staphylococcus aureus. Appl. Environ. Microbiol. 2012, 78, 2768-2774. [CrossRef]

159. Chakraborti, S.; Mandal, A.K.; Sarwar, S.; Singh, P.; Chakraborty, R.; Chakrabarti, P. Bactericidal effect of polyethyleneimine capped $\mathrm{ZnO}$ nanoparticles on multiple antibiotic resistant bacteria harboring genes of high-pathogenicity island. Colloids Surf. B Biointerfaces 2014, 121, 44-53. [CrossRef]

160. Shimizu, N.; Otsuka, K.; Sawada, H.; Maejima, T.; Shirotake, S. Bacteriolysis by vancomycin-conjugated acryl nanoparticles and morphological component analysis. Drug Dev. Ind. Pharm. 2014, 40, 813-818. [CrossRef]

161. Gu, H.; Ho, P.L.; Tsang, K.W.; Wang, L.; Xu, B. Using biofunctional magnetic nanoparticles to capture vancomycin-resistant enterococci and other gram-positive bacteria at ultralow concentration. J. Am. Chem. Soc. 2003, 125, 15702-15703. [CrossRef]

162. Shaik, N.; Pan, G.; Elmquist, W.F. Interactions of pluronic block copolymers on P-gp efflux activity: Experience with HIV-1 protease inhibitors. J. Pharm. Sci. 2008, 97, 5421-5433. [CrossRef]

163. Alipour, M.; Halwani, M.; Omri, A.; Suntres, Z.E. Antimicrobial effectiveness of liposomal polymyxin B against resistant Gram-negative bacterial strains. Int. J. Pharm. 2008, 355, 293-298. [CrossRef]

164. Aditya, N.P.; Vathsala, P.G.; Vieira, V.; Murthy, R.S.; Souto, E.B. Advances in nanomedicines for malaria treatment. Adv. Colloid Interface Sci. 2013, 201-202, 1-17. [CrossRef] [PubMed]

165. Chakraborty, S.P.; Sahu, S.K.; Pramanik, P.; Roy, S. In vitro antimicrobial activity of nanoconjugated vancomycin against drug resistant Staphylococcus aureus. Int. J. Pharm. 2012, 436, 659-676. [CrossRef] [PubMed]

166. Weder, N.; Zhang, H.; Jensen, K.; Yang, B.Z.; Simen, A.; Jackowski, A.; Lipschitz, D.; Douglas-Palumberi, H.; Ge, M.; Perepletchikova, F.; et al. Child abuse, depression, and methylation in genes involved with stress, neural plasticity, and brain circuitry. J. Am. Acad. Child. Adolesc. Psychiatry 2014, 53, 417-424.e5. [CrossRef] [PubMed]

167. Turos, E.; Reddy, G.S.; Greenhalgh, K.; Ramaraju, P.; Abeylath, S.C.; Jang, S.; Dickey, S.; Lim, D.V. Penicillin-bound polyacrylate nanoparticles: Restoring the activity of beta-lactam antibiotics against MRSA. Bioorg. Med. Chem. Lett. 2007, 17, 3468-3472. [CrossRef]

168. Wang, L.; Chen, Y.P.; Miller, K.P.; Cash, B.M.; Jones, S.; Glenn, S.; Benicewicz, B.C.; Decho, A.W. Functionalised nanoparticles complexed with antibiotic efficiently kill MRSA and other bacteria. Chem. Commun. (Camb) 2014, 50, 12030-12033. [CrossRef]

169. Hussein-Al-Ali, S.H.; El Zowalaty, M.E.; Hussein, M.Z.; Ismail, M.; Webster, T.J. Synthesis, characterization, controlled release, and antibacterial studies of a novel streptomycin chitosan magnetic nanoantibiotic. Int. J. Nanomed. 2014, 9, 549-557. [CrossRef]

170. Abeylath, S.C.; Turos, E.; Dickey, S.; Lim, D.V. Glyconanobiotics: Novel carbohydrated nanoparticle antibiotics for MRSA and Bacillus anthracis. Bioorg. Med. Chem. 2008, 16, 2412-2418. [CrossRef]

171. Falconer, J.; Murphy, A.N.; Young, S.P.; Clark, A.R.; Tiziani, S.; Guma, M.; Buckley, C.D. Review: Synovial Cell Metabolism and Chronic Inflammation in Rheumatoid Arthritis. Arthritis Rheumatol. 2018, 70, 984-999. [CrossRef]

172. Lim, H.; Lee, S.H.; Lee, H.T.; Lee, J.U.; Son, J.Y.; Shin, W.; Heo, Y.S. Structural Biology of the TNFalpha Antagonists Used in the Treatment of Rheumatoid Arthritis. Int. J. Mol. Sci. 2018, 19. [CrossRef]

173. Horton, S.; Walsh, C.; Emery, P. Certolizumab pegol for the treatment of rheumatoid arthritis. Expert Opin. Biol. 2012, 12, 235-249. [CrossRef]

174. Yudoh, K.; Karasawa, R.; Masuko, K.; Kato, T. Water-soluble fullerene (C60) inhibits the development of arthritis in the rat model of arthritis. Int. J. Nanomed. 2009, 4, 217-225. [CrossRef] [PubMed] 
175. de Castro, S.; Camarasa, M.J. Polypharmacology in HIV inhibition: Can a drug with simultaneous action against two relevant targets be an alternative to combination therapy? Eur. J. Med. Chem. 2018, 150, $206-227$. [CrossRef] [PubMed]

176. Herskovitz, J.; Gendelman, H.E. HIV and the Macrophage: From Cell Reservoirs to Drug Delivery to Viral Eradication. J. Neuroimmune Pharm. 2019, 14, 52-67. [CrossRef] [PubMed]

177. Dutta, T.; Garg, M.; Jain, N.K. Targeting of efavirenz loaded tuftsin conjugated poly(propyleneimine) dendrimers to HIV infected macrophages in vitro. Eur. J. Pharm. Sci. 2008, 34, 181-189. [CrossRef] [PubMed]

178. Dembri, A.; Montisci, M.J.; Gantier, J.C.; Chacun, H.; Ponchel, G. Targeting of 3'-azido 3'-deoxythymidine (AZT)-loaded poly(isohexylcyanoacrylate) nanospheres to the gastrointestinal mucosa and associated lymphoid tissues. Pharm. Res. 2001, 18, 467-473. [CrossRef] [PubMed]

179. Lobenberg, R.; Maas, J.; Kreuter, J. Improved body distribution of 14C-labelled AZT bound to nanoparticles in rats determined by radioluminography. J. Drug Target. 1998, 5, 171-179. [CrossRef]

180. Dutta, T.; Agashe, H.B.; Garg, M.; Balakrishnan, P.; Kabra, M.; Jain, N.K. Poly (propyleneimine) dendrimer based nanocontainers for targeting of efavirenz to human monocytes/macrophages in vitro. J. Drug Target. 2007, 15, 89-98. [CrossRef]

181. Pham, K.; Li, D.; Guo, S.; Penzak, S.; Dong, X. Development and in vivo evaluation of child-friendly lopinavir/ritonavir pediatric granules utilizing novel in situ self-assembly nanoparticles. J. Control. Release 2016, 226, 88-97. [CrossRef]

182. Liptrott, N.J.; Giardiello, M.; McDonald, T.O.; Rannard, S.P.; Owen, A. Assessment of interactions of efavirenz solid drug nanoparticles with human immunological and haematological systems. J. Nanobiotechnol. 2018, 16, 22. [CrossRef]

183. Govender, T.; Ojewole, E.; Naidoo, P.; Mackraj, I. Polymeric nanoparticles for enhancing antiretroviral drug therapy. Drug Deliv. 2008, 15, 493-501. [CrossRef]

184. Shah, L.K.; Amiji, M.M. Intracellular delivery of saquinavir in biodegradable polymeric nanoparticles for HIV/AIDS. Pharm. Res. 2006, 23, 2638-2645. [CrossRef]

185. Garg, M.; Asthana, A.; Agashe, H.B.; Agrawal, G.P.; Jain, N.K. Stavudine-loaded mannosylated liposomes: In-vitro anti-HIV-I activity, tissue distribution and pharmacokinetics. J. Pharm. Pharm. 2006, 58, 605-616. [CrossRef] [PubMed]

186. Neeland, I.J.; Poirier, P.; Despres, J.P. Cardiovascular and Metabolic Heterogeneity of Obesity: Clinical Challenges and Implications for Management. Circulation 2018, 137, 1391-1406. [CrossRef]

187. Haeri, A.; Sadeghian, S.; Rabbani, S.; Anvari, M.S.; Ghassemi, S.; Radfar, F.; Dadashzadeh, S. Effective attenuation of vascular restenosis following local delivery of chitosan decorated sirolimus liposomes. Carbohydr. Polym. 2017, 157, 1461-1469. [CrossRef] [PubMed]

188. Arzani, G.; Haeri, A.; Daeihamed, M.; Bakhtiari-Kaboutaraki, H.; Dadashzadeh, S. Niosomal carriers enhance oral bioavailability of carvedilol: Effects of bile salt-enriched vesicles and carrier surface charge. Int. J. Nanomed. 2015, 10, 4797-4813. [CrossRef]

189. Neves, A.R.; Lucio, M.; Martins, S.; Lima, J.L.; Reis, S. Novel resveratrol nanodelivery systems based on lipid nanoparticles to enhance its oral bioavailability. Int. J. Nanomed. 2013, 8, 177-187. [CrossRef]

190. Formiga, F.R.; Pelacho, B.; Garbayo, E.; Abizanda, G.; Gavira, J.J.; Simon-Yarza, T.; Mazo, M.; Tamayo, E.; Jauquicoa, C.; Ortiz-de-Solorzano, C.; et al. Sustained release of VEGF through PLGA microparticles improves vasculogenesis and tissue remodeling in an acute myocardial ischemia-reperfusion model. J. Control. Release 2010, 147, 30-37. [CrossRef]

191. Simon-Yarza, T.; Formiga, F.R.; Tamayo, E.; Pelacho, B.; Prosper, F.; Blanco-Prieto, M.J. PEGylated-PLGA microparticles containing VEGF for long term drug delivery. Int. J. Pharm. 2013, 440, 13-18. [CrossRef]

192. Phillips, M.A.; Gran, M.L.; Peppas, N.A. Targeted Nanodelivery of Drugs and Diagnostics. Nano Today 2010, 5, 143-159. [CrossRef]

193. Pardridge, W.M. Drug transport across the blood-brain barrier. J. Cereb Blood Flow Metab. 2012, 32, $1959-1972$. [CrossRef]

194. Wohlfart, S.; Gelperina, S.; Kreuter, J. Transport of drugs across the blood-brain barrier by nanoparticles. J. Control. Release 2012, 161, 264-273. [CrossRef] [PubMed]

195. Liu, H.L.; Fan, C.H.; Ting, C.Y.; Yeh, C.K. Combining microbubbles and ultrasound for drug delivery to brain tumors: Current progress and overview. Theranostics 2014, 4, 432-444. [CrossRef] [PubMed] 
196. Klafki, H.W.; Staufenbiel, M.; Kornhuber, J.; Wiltfang, J. Therapeutic approaches to Alzheimer's disease. Brain 2006, 129, 2840-2855. [CrossRef]

197. Wilson, B.; Samanta, M.K.; Santhi, K.; Kumar, K.P.; Paramakrishnan, N.; Suresh, B. Poly(n-butylcyanoacrylate) nanoparticles coated with polysorbate 80 for the targeted delivery of rivastigmine into the brain to treat Alzheimer's disease. Brain Res. 2008, 1200, 159-168. [CrossRef] [PubMed]

198. Patel, H.N.; Patel, P.M. Dendrimer applications - A review. Int. J. Pharma Bio Sci. 2013, 4, 454-463.

199. Laserra, S.; Basit, A.; Sozio, P.; Marinelli, L.; Fornasari, E.; Cacciatore, I.; Ciulla, M.; Turkez, H.; Geyikoglu, F.; Di Stefano, A. Solid lipid nanoparticles loaded with lipoyl-memantine codrug: Preparation and characterization. Int. J. Pharm. 2015, 485, 183-191. [CrossRef] [PubMed]

200. Saraiva, C.; Praca, C.; Ferreira, R.; Santos, T.; Ferreira, L.; Bernardino, L. Nanoparticle-mediated brain drug delivery: Overcoming blood-brain barrier to treat neurodegenerative diseases. J. Control. Release 2016, 235, 34-47. [CrossRef] [PubMed]

201. Hu, H.; Qiao, Y.; Meng, F.; Liu, X.; Ding, C. Enhanced apatite-forming ability and cytocompatibility of porous and nanostructured $\mathrm{TiO} 2 / \mathrm{CaSiO} 3$ coating on titanium. Colloids Surf. B Biointerfaces 2013, 101, 83-90. [CrossRef]

202. Joshi, S.A.; Chavhan, S.S.; Sawant, K.K. Rivastigmine-loaded PLGA and PBCA nanoparticles: Preparation, optimization, characterization, in vitro and pharmacodynamic studies. Eur. J. Pharm. Biopharm. 2010, 76, 189-199. [CrossRef]

203. Tapeinos, C.; Battaglini, M.; Ciofani, G. Advances in the design of solid lipid nanoparticles and nanostructured lipid carriers for targeting brain diseases. J. Control. Release 2017, 264, 306-332. [CrossRef]

204. Silva Adaya, D.; Aguirre-Cruz, L.; Guevara, J.; Ortiz-Islas, E. Nanobiomaterials' applications in neurodegenerative diseases. J. Biomater Appl. 2017, 31, 953-984. [CrossRef] [PubMed]

205. Fernandez, H.H. Updates in the medical management of Parkinson disease. Cleve Clin. J. Med. 2012, 79, 28-35. [CrossRef] [PubMed]

206. MacDonald, P.A.; MacDonald, A.A.; Seergobin, K.N.; Tamjeedi, R.; Ganjavi, H.; Provost, J.S.; Monchi, O. The effect of dopamine therapy on ventral and dorsal striatum-mediated cognition in Parkinson's disease: Support from functional MRI. Brain 2011, 134, 1447-1463. [CrossRef] [PubMed]

207. Kulkarni, A.D.; Vanjari, Y.H.; Sancheti, K.H.; Belgamwar, V.S.; Surana, S.J.; Pardeshi, C.V. Nanotechnology-mediated nose to brain drug delivery for Parkinson's disease: A mini review. J. Drug Target. 2015, 23, 775-788. [CrossRef] [PubMed]

208. Azeem, A.; Talegaonkar, S.; Negi, L.M.; Ahmad, F.J.; Khar, R.K.; Iqbal, Z. Oil based nanocarrier system for transdermal delivery of ropinirole: A mechanistic, pharmacokinetic and biochemical investigation. Int. J. Pharm. 2012, 422, 436-444. [CrossRef] [PubMed]

209. Md, S.; Khan, R.A.; Mustafa, G.; Chuttani, K.; Baboota, S.; Sahni, J.K.; Ali, J. Bromocriptine loaded chitosan nanoparticles intended for direct nose to brain delivery: Pharmacodynamic, pharmacokinetic and scintigraphy study in mice model. Eur. J. Pharm. Sci. 2013, 48, 393-405. [CrossRef]

210. Gendelman, H.E.; Anantharam, V.; Bronich, T.; Ghaisas, S.; Jin, H.; Kanthasamy, A.G.; Liu, X.; McMillan, J.; Mosley, R.L.; Narasimhan, B.; et al. Nanoneuromedicines for degenerative, inflammatory, and infectious nervous system diseases. Nanomed. -Uk 2015, 11, 751-767. [CrossRef]

211. Batrakova, E.V.; Li, S.; Reynolds, A.D.; Mosley, R.L.; Tatiana, K.; Kabanov, A.V.; Gendelman, H.E. A Macrophage-Nanozyme Delivery System for Parkinson's Disease. NIH Public Access. 2009, 18, 1498-1506. [CrossRef]

212. Crotty, S.; Fitzgerald, P.; Tuohy, E.; Harris, D.M.; Fisher, A.; Mandel, A.; Bolton, A.E.; Sullivan, A.M.; Nolan, Y. Neuroprotective effects of novel phosphatidylglycerol-based phospholipids in the 6-hydroxydopamine model of Parkinson's disease. Eur. J. Neurosci. 2008, 27, 294-300. [CrossRef]

213. Xia, C.F.; Boado, R.J.; Zhang, Y.; Chu, C.; Pardridge, W.M. Intravenous glial-derived neurotrophic factor gene therapy of experimental Parkinson's disease with Trojan horse liposomes and a tyrosine hydroxylase promoter. J. Gene Med. 2008, 10, 306-315. [CrossRef]

214. Konishi, M.; Kawamoto, K.; Izumikawa, M.; Kuriyama, H.; Yamashita, T. Gene transfer into guinea pig cochlea using adeno-associated virus vectors. J. Gene Med. 2008, 10, 610-618. [CrossRef]

215. Huang, R.; Ke, W.; Liu, Y.; Wu, D.; Feng, L.; Jiang, C.; Pei, Y. Gene therapy using lactoferrin-modified nanoparticles in a rotenone-induced chronic Parkinson model. J. Neurol. Sci. 2010, 290, 123-130. [CrossRef] [PubMed] 
216. Lindvall, O.; Bjorklund, A. Cell therapeutics in Parkinson's disease. Neurotherapeutics 2011, 8, 539-548. [CrossRef] [PubMed]

217. Davis, S.S. Biomedical applications of nanotechnology-Implications for drug targeting and gene therapy. Trends Biotechnol. 1997, 15, 217-224. [CrossRef]

218. Yurek, D.M.; Flectcher, A.M.; Kowalczyk, T.H.; Padegimas, L.; Cooper, J. Compacted DNA nanoparticle gene transfer of GDNF to the rat striatum enhances the survival of grafted fetal dopamine neurons. NIH Public Access. 2009, 18, 1183-1196. [CrossRef]

219. Bondi, M.L.; Craparo, E.F.; Giammona, G.; Drago, F. Brain-targeted solid lipid nanoparticles containing riluzole: Preparation, characterization and biodistribution. Nanomedicine (Lond) 2010, 5, 25-32. [CrossRef]

220. Mazibuko, Z.; Choonara, Y.E.; Kumar, P.; Du Toit, L.C.; Modi, G.; Naidoo, D.; Pillay, V. A review of the potential role of nano-enabled drug delivery technologies in amyotrophic lateral sclerosis: Lessons learned from other neurodegenerative disorders. J. Pharm. Sci. 2015, 104, 1213-1229. [CrossRef]

221. Basso, A.S.; Frenkel, D.; Quintana, F.J.; Costa-Pinto, F.A.; Petrovic-Stojkovic, S.; Puckett, L.; Monsonego, A.; Bar-Shir, A.; Engel, Y.; Gozin, M.; et al. Reversal of axonal loss and disability in a mouse model of progressive multiple sclerosis. J. Clin. Investig. 2008, 118, 1532-1543. [CrossRef]

222. Bell, C.; Anderson, J.; Ganguly, T.; Prescott, J.; Capila, I.; Lansing, J.C.; Sachleben, R.; Iyer, M.; Fier, I.; Roach, J.; et al. Development of Glatopa(R) (Glatiramer Acetate): The First FDA-Approved Generic Disease-Modifying Therapy for Relapsing Forms of Multiple Sclerosis. J. Pharm. Pr. 2018, 31, 481-488. [CrossRef]

223. Sharaf, M.G.; Cetinel, S.; Heckler, L.; Damji, K.; Unsworth, L.; Montemagno, C. Nanotechnology-Based Approaches for Ophthalmology Applications: Therapeutic and Diagnostic Strategies. Asia Pac. J. Ophthalmol (Phila) 2014, 3, 172-180. [CrossRef]

224. Diebold, Y.; Calonge, M. Applications of nanoparticles in ophthalmology. Prog. Retin Eye Res. 2010, 29, 596-609. [CrossRef] [PubMed]

225. Puglia, C.; Offerta, A.; Carbone, C.; Bonina, F.; Pignatello, R.; Puglisi, G. Lipid nanocarriers (LNC) and their applications in ocular drug delivery. Curr. Med. Chem. 2015, 22, 1589-1602. [CrossRef] [PubMed]

226. Weng, Y.; Liu, J.; Jin, S.; Guo, W.; Liang, X.; Hu, Z. Nanotechnology-based strategies for treatment of ocular disease. Acta Pharm. Sin. B 2017, 7, 281-291. [CrossRef]

227. Abrego, G.; Alvarado, H.; Souto, E.B.; Guevara, B.; Bellowa, L.H.; Parra, A.; Calpena, A.; Garcia, M.L. Biopharmaceutical profile of pranoprofen-loaded PLGA nanoparticles containing hydrogels for ocular administration. Eur. J. Pharm. Biopharm. 2015, 95, 261-270. [CrossRef] [PubMed]

228. Asasutjarit, R.; Theerachayanan, T.; Kewsuwan, P.; Veeranodha, S.; Fuongfuchat, A.; Ritthidej, G.C. Development and Evaluation of Diclofenac Sodium Loaded-N-Trimethyl Chitosan Nanoparticles for Ophthalmic Use. Aaps Pharmscitech 2015, 16, 1013-1024. [CrossRef] [PubMed]

229. Fabiano, A.; Chetoni, P.; Zambito, Y. Mucoadhesive nano-sized supramolecular assemblies for improved pre-corneal drug residence time. Drug Dev. Ind. Pharm. 2015, 41, 2069-2076. [CrossRef]

230. El-Salamounia, N.S.; Farida, R.M. Recent Drug Delivery Systems for Treatment of Glaucoma. Glaucoma 2016, 1-13.

231. Ibrahim, M.M.; Abd-Elgawad, A.H.; Soliman, O.A.; Jablonski, M.M. Natural Bioadhesive Biodegradable Nanoparticle-Based Topical Ophthalmic Formulations for Management of Glaucoma. Transl. Vis. Sci. Technol. 2015, 4, 12. [CrossRef]

232. Cetinel, S.; Montemagno, C. Nanotechnology Applications for Glaucoma. Asia Pac. J. Ophthalmol. (Phila) 2016, 5, 70-78. [CrossRef]

233. Pan, Q.; Xu, Q.; Boylan, N.J.; Lamb, N.W.; Emmert, D.G.; Yang, J.C.; Tang, L.; Heflin, T.; Alwadani, S.; Eberhart, C.G.; et al. Corticosteroid-loaded biodegradable nanoparticles for prevention of corneal allograft rejection in rats. J. Control. Release 2015, 201, 32-40. [CrossRef]

234. Joseph, R.R.; Venkatraman, S.S. Drug delivery to the eye: What benefits do nanocarriers offer? Nanomedicine (Lond) 2017, 12, 683-702. [CrossRef] [PubMed]

235. Sugawara, E.; Nikaido, H. Properties of AdeABC and AdeIJK efflux systems of Acinetobacter baumannii compared with those of the AcrAB-TolC system of Escherichia coli. Antimicrob. Agents Chemother. 2014, 58, 7250-7257. [CrossRef] [PubMed]

236. Yhee, J.Y.; Im, J.; Nho, R.S. Advanced Therapeutic Strategies for Chronic Lung Disease Using Nanoparticle-Based Drug Delivery. J. Clin. Med. 2016, 5, 82. [CrossRef] [PubMed] 
237. Lim, Y.H.; Tiemann, K.M.; Hunstad, D.A.; Elsabahy, M.; Wooley, K.L. Polymeric nanoparticles in development for treatment of pulmonary infectious diseases. Wiley Interdiscip. Rev. Nanomed. Nanobiotechnol. 2016, 8, 842-871. [CrossRef] [PubMed]

238. Nasr, M.; Najlah, M.; D’Emanuele, A.; Elhissi, A. PAMAM dendrimers as aerosol drug nanocarriers for pulmonary delivery via nebulization. Int. J. Pharm. 2014, 461, 242-250. [CrossRef]

239. Mohamud, R.; Xiang, S.D.; Selomulya, C.; Rolland, J.M.; O’Hehir, R.E.; Hardy, C.L.; Plebanski, M. The effects of engineered nanoparticles on pulmonary immune homeostasis. Drug Metab. Rev. 2014, 46, 176-190. [CrossRef]

240. Gera, S.; Sampathi, S.; Dodoala, S. Role of Nanoparticles in Drug Delivery and Regenerative Therapy for Bone Diseases. Curr. Drug Deliv. 2017, 14, 904-916. [CrossRef]

241. Alves Cardoso, D.; Jansen, J.A.; Leeuwenburgh, S.C. Synthesis and application of nanostructured calcium phosphate ceramics for bone regeneration. J. Biomed. Mater. Res. B Appl. Biomater. 2012, 100, 2316-2326. [CrossRef]

242. Ding, X.; Wang, Y. Weak Bond-Based Injectable and Stimuli Responsive Hydrogels for Biomedical Applications. J. Mater. Chem. B 2017, 5, 887-906. [CrossRef]

243. Unal, S.; Ekren, N.; Sengil, A.Z.; Oktar, F.N.; Irmak, S.; Oral, O.; Sahin, Y.M.; Kilic, O.; Agathopoulos, S.; Gunduz, O. Synthesis, characterization, and biological properties of composites of hydroxyapatite and hexagonal boron nitride. J. Biomed. Mater. Res. B Appl. Biomater. 2018, 106, 2384-2392. [CrossRef]

244. Ortega-Oller, I.; Padial-Molina, M.; Galindo-Moreno, P.; O’Valle, F.; Jodar-Reyes, A.B.; Peula-Garcia, J.M. Bone Regeneration from PLGA Micro-Nanoparticles. Biomed. Res. Int. 2015, 2015, 415289. [CrossRef] [PubMed]

245. Park, J.S.; Yi, S.W.; Kim, H.J.; Kim, S.M.; Park, K.H. Regulation of Cell Signaling Factors Using PLGA Nanoparticles Coated/Loaded with Genes and Proteins for Osteogenesis of Human Mesenchymal Stem Cells. Acs Appl. Mater. Interfaces 2016, 8, 30387-30397. [CrossRef] [PubMed]

246. Kong, Z.; Lin, J.; Yu, M.; Yu, L.; Li, J.; Weng, W.; Cheng, K.; Wang, H. Enhanced loading and controlled release of rhBMP-2 in thin mineralized collagen coatings with the aid of chitosan nanospheres and its biological evaluations. J. Mater. Chem. B 2014, 2, 4572-4582. [CrossRef]

247. Zhang, S.; Kucharski, C.; Doschak, M.R.; Sebald, W.; Uludag, H. Polyethylenimine-PEG coated albumin nanoparticles for BMP-2 delivery. Biomaterials 2010, 31, 952-963. [CrossRef] [PubMed]

248. Giger, E.V.; Castagner, B.; Leroux, J.C. Biomedical applications of bisphosphonates. J. Control. Release 2013, 167, 175-188. [CrossRef] [PubMed]

249. Loh, X.J.; Lee, T.C.; Dou, Q.; Deen, G.R. Utilising inorganic nanocarriers for gene delivery. Biomater. Sci. 2016, 4, 70-86. [CrossRef]

250. FDA. EquivaBone Osteoinductive Bone Graft Substitute. Available online: https://www.accessdata.fda.gov/ cdrh_docs/pdf9/K090855.pdf (accessed on 11 March 2020).

251. Warabi, S.; Tachibana, Y.; Kumegawa, M.; Hakeda, Y. Dexamethasone inhibits bone resorption by indirectly inducing apoptosis of the bone-resorbing osteoclasts via the action of osteoblastic cells. Cytotechnology 2001, 35, 25-34. [CrossRef]

252. Goncalves, R.M.; Pereira, A.C.; Pereira, I.O.; Oliveira, M.J.; Barbosa, M.A. Macrophage response to chitosan/poly-(gamma-glutamic acid) nanoparticles carrying an anti-inflammatory drug. J. Mater. Sci Mater. Med. 2015, 26, 167. [CrossRef]

253. Ferrari, M. Cancer nanotechnology: Opportunities and challenges. Nat. Rev. Cancer 2005, 5, $161-171$. [CrossRef]

254. Su, C.K.; Sun, Y.C. In vivo monitoring of distributional transport kinetics and extravasation of quantum dots in living rat liver. Nanotechnology 2013, 24, 165101. [CrossRef]

255. Chang, S.; Chen, D.; Kang, B.; Dai, Y. UV-enhanced cytotoxicity of CdTe quantum dots in PANC-1 cells depend on their size distribution and surface modification. J. Nanosci. Nanotechnol. 2013, 13, 751-754. [CrossRef] [PubMed]

256. Angra, P.K.; Rizvi, S.A.A.; Oettinger, C.W.; D'Souza, M.J. Novel approach for preparing nontoxic stealth microspheres for drug delivery. Eur. J. Chem. 2011, 2, 125-129. [CrossRef]

257. Li, D.; Kaner, R.B. Shape and aggregation control of nanoparticles: Not shaken, not stirred. J. Am. Chem. Soc. 2006, 128, 968-975. [CrossRef] [PubMed] 
258. Rizvi, S.A.A.; Saleh, A.M. Applications of nanoparticle systems in drug delivery technology. Saudi Pharm. J. 2018, 26, 64-70. [CrossRef]

259. Sadauskas, E.; Danscher, G.; Stoltenberg, M.; Vogel, U.; Larsen, A.; Wallin, H. Protracted elimination of gold nanoparticles from mouse liver. Nanomed. -Uk 2009, 5, 162-169. [CrossRef]

260. Li, S.-D.; Huang, L. Stealth Nanoparticles: High Density but Sheddable PEG is a Key for Tumor Targeting. J. Control. Release 2010, 145, 178-181. [CrossRef]

261. Manzoor, A.A.; Lindner, L.H.; Landon, C.D.; Park, J.Y.; Simnick, A.J.; Dreher, M.R.; Das, S.; Hanna, G.; Park, W.; Chilkoti, A.; et al. Overcoming limitations in nanoparticle drug delivery: Triggered, intravascular release to improve drug penetration into tumors. Cancer Res. 2012, 72, 5566-5575. [CrossRef]

262. Fan, J.; Wang, S.; Zhang, X.; Chen, W.; Li, Y.; Yang, P.; Cao, Z.; Wang, Y.; Lu, W.; Ju, D. Quantum Dots Elicit Hepatotoxicity through Lysosome-Dependent Autophagy Activation and Reactive Oxygen Species Production. Acs Biomater. Sci. Eng. 2018, 4, 1418-1427. [CrossRef]

263. Lu, Y.; Xu, S.; Chen, H.; He, M.; Deng, Y.; Cao, Z.; Pi, H.; Chen, C.; Li, M.; Ma, Q.; et al. CdSe/ZnS quantum dots induce hepatocyte pyroptosis and liver inflammation via NLRP3 inflammasome activation. Biomaterials 2016, 90, 27-39. [CrossRef]

264. Grabowska-Jadach, I.; Zuchowska, A.; Olesik, M.; Drozd, M.; Pietrzak, M.; Malinowska, E.; Brzozka, Z. Cytotoxicity studies of selected cadmium-based quantum dots on 2D vs. 3D cell cultures. New J. Chem. 2018, 42, 12787-12795. [CrossRef]

265. Shao, D.; Li, J.; Guan, F.; Pan, Y.; Xiao, X.; Zhang, M.; Zhang, H.; Chen, L. Selective inhibition of liver cancer growth realized by the intrinsic toxicity of a quantum dot-lipid complex. Int. J. Nanomed. 2014, 9, 5753-5769. [CrossRef] [PubMed]

(C) 2020 by the authors. Licensee MDPI, Basel, Switzerland. This article is an open access article distributed under the terms and conditions of the Creative Commons Attribution (CC BY) license (http://creativecommons.org/licenses/by/4.0/). 